\title{
Recent Progress on Sulfated Nanozirconia as a Solid Acid Catalyst in the Hydrocracking Reaction
}

\author{
Serly Jolanda Sekewael ${ }^{1}$, Remi Ayu Pratika ${ }^{2}$, , Latifah Hauli ${ }^{2} \mathbb{D}$, Amalia Kurnia Amin ${ }^{2} \mathbb{D}$, Maisari Utami $^{3}$ \\ and Karna Wijaya ${ }^{2, *}$
}

check for updates

Citation: Sekewael, S.J.; Pratika, R.A.; Hauli, L.; Amin, A.K.; Utami, M.; Wijaya, K. Recent Progress on Sulfated Nanozirconia as a Solid Acid Catalyst in the Hydrocracking Reaction. Catalysts 2022, 12, 191. https://doi.org/10.3390/ catal12020191

Academic Editors: Elisabeth Egholm Jacobsen, Simona M. Coman and Madalina Tudorache

Received: 17 December 2021

Accepted: 27 January 2022

Published: 3 February 2022

Publisher's Note: MDPI stays neutral with regard to jurisdictional claims in published maps and institutional affiliations.

Copyright: (c) 2022 by the authors. Licensee MDPI, Basel, Switzerland. This article is an open access article distributed under the terms and conditions of the Creative Commons Attribution (CC BY) license (https:// creativecommons.org/licenses/by/ $4.0 /)$.
1 Department of Chemistry, Faculty of Mathematics and Natural Science, University of Pattimura, Ambon 97235, Indonesia; sjsekewael@yahoo.com

2 Department of Chemistry, Faculty of Mathematics and Natural Science, Universitas Gadjah Mada, Yogyakarta 55281, Indonesia; remi.ayu.pratika@mail.ugm.ac.id (R.A.P.); latifah.hauli@mail.ugm.ac.id (L.H.); amalia.kurnia.a@mail.ugm.ac.id (A.K.A.)

3 Department of Chemistry, Faculty of Mathematics and Natural Sciences, Universitas Islam Indonesia, Yogyakarta 55281, Indonesia; maisariutami@uii.ac.id

* Correspondence: karnawijaya@ugm.ac.id

\begin{abstract}
Zirconia has advantageous thermal stability and acid-base properties. The acidity character of $\mathrm{ZrO}_{2}$ can be enhanced through the sulfation process forming sulfated zirconia $\left(\mathrm{ZrO}_{2}-\mathrm{SO}_{4}\right)$. An acidity test of the catalyst produced proved that the sulfate loading succeeded in increasing the acidity of $\mathrm{ZrO}_{2}$ as confirmed by the presence of characteristic absorptions of the sulfate group from the FTIR spectra of the catalyst. The $\mathrm{ZrO}_{2}-\mathrm{SO}_{4}$ catalyst can be further modified with transition metals, such as Platinum (Pt), Chromium (Cr), and Nickel (Ni) to increase catalytic activity and catalyst stability. It was observed that variations in the concentrations of $\mathrm{Pt}, \mathrm{Cr}$, and $\mathrm{Ni}$ produced a strong influence on the catalytic activity as the acidity and porosity of the catalyst increased with their addition. The activity, selectivity, and catalytic stability tests of $\mathrm{Pt} / \mathrm{ZrO}_{2}-\mathrm{SO}_{4}, \mathrm{Cr} / \mathrm{ZrO}_{2}-\mathrm{SO}_{4}$ and $\mathrm{Ni} / \mathrm{ZrO}_{2}-\mathrm{SO}_{4}$ were carried out with their application in the hydrocracking reaction to produce liquid fuel. The percentage of liquid fractions produced using these catalysts were higher than the fraction produced using pure $\mathrm{ZrO}_{2}$ and $\mathrm{ZrO}_{2}-\mathrm{SO}_{4}$ catalyst.
\end{abstract}

Keywords: catalyst; zirconia; sulfated; acidity

\section{Introduction}

Zirconium dioxide, known as zirconia, is a crystalline oxide of zirconium that found form in the mineral baddeleyite. Zirconia is a white material that does not react with water or another solvent, and that has acid-base properties and excellent thermal dan chemical stabilization. $\mathrm{ZrO}_{2}$ materials are of wide interest and development in their application in various fields, such as heterogeneous catalyst, optics, electronics, magnetics, and ceramics owing to the high melting point $\left(\geq 2700^{\circ} \mathrm{C}\right)$, low thermal conductivity, corrosion resistance, and good thermal and mechanical strength [1-3].

Modification of zirconia to increase its catalytic activity has been developed. Many studies have showed that modification zirconia such as sulfated process or metal supported was effective during the chemical process [3-5]. Sulfated zirconia catalyst via hydrothermal treatment for hydrocracking of LDPE plastic waste into liquid fuels was examined by Utami et al. [6]. The total acidity of zirconia increased after the sulfation process, thus increasing the amount of liquid yield. However, the catalytic activity of sulfated zirconia catalyst during the hydrocracking reaction at high temperature decreases due to the deactivation catalyst. This process therefore requires an appropriate catalyst to increase the catalytic activity of sulfated zirconia, as well as the acidity and liquid yield $[7,8]$.

Supported noble metals such as Platinum (Pt), Chromium $(\mathrm{Cr})$, and Nickel (Ni) as a promoter have shown good catalytic activity in the hydrocracking reaction. The synthesis 
of Pt/sulfated zirconia [9], $\mathrm{Cr}$ /sulfated zirconia [10], and $\mathrm{Ni} /$ sulfated zirconia [11] catalyst in the hydrocracking reaction reported the enhance of acidity of sulfated zirconia and the liquid product of hydrocracking after the addition of promoter $\mathrm{Pt}, \mathrm{Cr}$, and $\mathrm{Ni}$, respectively.

\section{Zirconium Dioxide $\left(\mathrm{ZrO}_{2}\right)$}

Zirconium dioxide $\left(\mathrm{ZrO}_{2}\right)$ is a polymorphic material with three crystalline phases, namely the monoclinic, tetragonal, and cubic phases, as shown in Figure 1 . The monoclinic and tetragonal phases are stable up to temperatures of 1170 and $2360{ }^{\circ} \mathrm{C}$, respectively, while the cubic phase is stable at temperatures above $2680{ }^{\circ} \mathrm{C} . \mathrm{ZrO}_{2}$ as a catalyst is normally used in its monoclinic and metastable tetragonal crystalline phases [12-14]. Transformation of the crystalline phases of $\mathrm{ZrO}_{2}$ is driven by changes in temperature. $\mathrm{ZrO}_{2}$ calcined at $<800{ }^{\circ} \mathrm{C}$ forms monoclinic and metastable tetragonal phases $[15,16]$.

The transformations of one $\mathrm{ZrO}_{2}$ phase to another are accompanied by changes in lattice parameters. The rate of phase transformation of $\mathrm{ZrO}_{2}$ is also influenced by the particle size of the $\mathrm{ZrO}_{2}$ precursor used. The larger the $\mathrm{ZrO}_{2}$ particle size, the faster the phase transformation occurs. Nano-sized particles have a high surface area, allowing for more of the atoms of the particles to interact and form bonds $[15,17,18]$. Based on surface properties and polymorphic form, $\mathrm{ZrO}_{2}$ is also often used as a catalyst or carrier material because it has acidic and basic properties $[19,20]$. In addition, $\mathrm{ZrO}_{2}$ has a structure with vacant sites on its surface that can allow cations to easily enter [21,22].

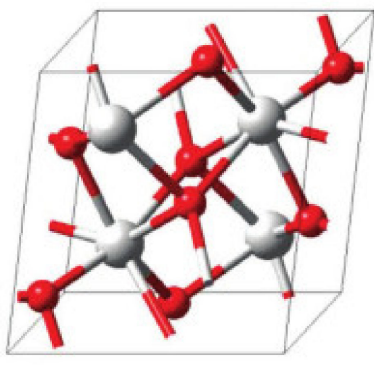

(a)

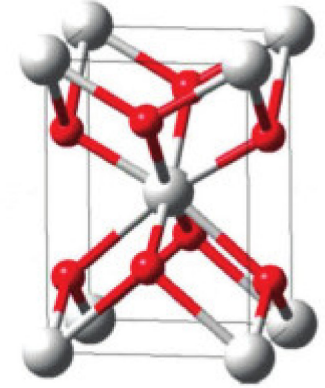

(b)

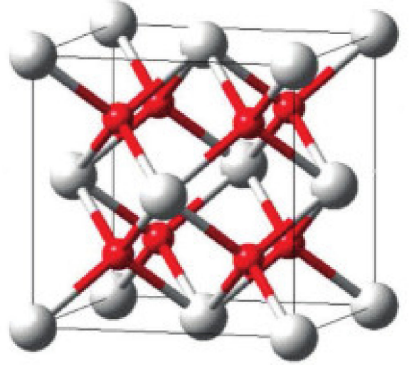

(c)

Figure 1. Crystal structures of (a) monoclinic, (b) tetragonal, and (c) cubic $\mathrm{ZrO}_{2}$. Copyright Elsevier, reprinted from Ref. [23].

\section{3. $\mathrm{ZrO}_{2}-\mathrm{SO}_{4}$ Catalyst}

Zirconia is a catalyst containing high Lewis acid sites. Ore [15] mentioned that $\mathrm{ZrO}_{2}$ can be modified with acid or base to achieve, based on the intended application, the appropriate and desired strong acid or base characteristics. Sulfation is a method that can increase the strength of $\mathrm{ZrO}_{2}$ acid through the formation of Brønsted acids on the zirconia substrate that consequently increases its catalytic activity. $\mathrm{ZrO}_{2}-\mathrm{SO}_{4}$ can be prepared from sulfate precursors such as $\mathrm{H}_{2} \mathrm{SO}_{4},\left(\mathrm{NH}_{4}\right)_{2} \mathrm{SO}_{4},\left(\mathrm{NH}_{4}\right)_{2} \mathrm{~S}_{2} \mathrm{O}_{3}$, and $\left.\left(\mathrm{NH}_{4}\right)_{2} \mathrm{~S}\right)$ [24-26].

The formation of $\mathrm{ZrO}_{2}-\mathrm{SO}_{4}$ occurs through the chelation of the zirconium cations $\left(\mathrm{Zr}^{4+}\right)$ with sulfate ions. The $\mathrm{SO}_{4}{ }^{2-}$ ions acts as ligands that donate their lone pair of electrons from the $\mathrm{O}$ atom, thus forming a coordination bond with two $\mathrm{Zr}^{4+}$ as the central atoms and causing the acid molecule to release two protons simultaneously. After relaxation, adsorptive complex molecules are produced from the coordination of $\mathrm{SO}_{4}{ }^{2-}$ ions onto the $\mathrm{ZrO}_{2}$ surface through the sharing of two O atoms [27-29]. Saravan et al. [30] illustrate the surface model of $\mathrm{ZrO}_{2}-\mathrm{SO}_{4}$ with the Lewis and Brønsted acid sites shown as shown in Figure 2. 


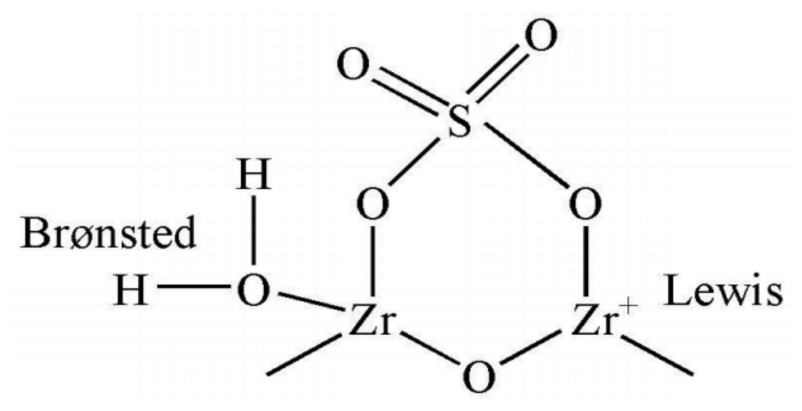

Figure 2. Brønsted and Lewis acid sites on $\mathrm{ZrO}_{2}-\mathrm{SO}_{4}$. Copyright MDPI, reprinted from Ref. [17].

Modification of zirconia to $\mathrm{ZrO}_{2}-\mathrm{SO}_{4}$ produces materials with high Lewis and Brønsted acid strengths. Wang et al. [29] presented an illustration of the $\mathrm{ZrO}_{2}-\mathrm{SO}_{4}$ surface as presented in Figure 3. The high acid strength of the Brønsted acid site is associated with the location of $\mathrm{Zr}^{4+}$ ions that are adjacent to the $\mathrm{S}=\mathrm{O}$ bond which attracts electrons from the bisulfate to form the Brønsted acid site.

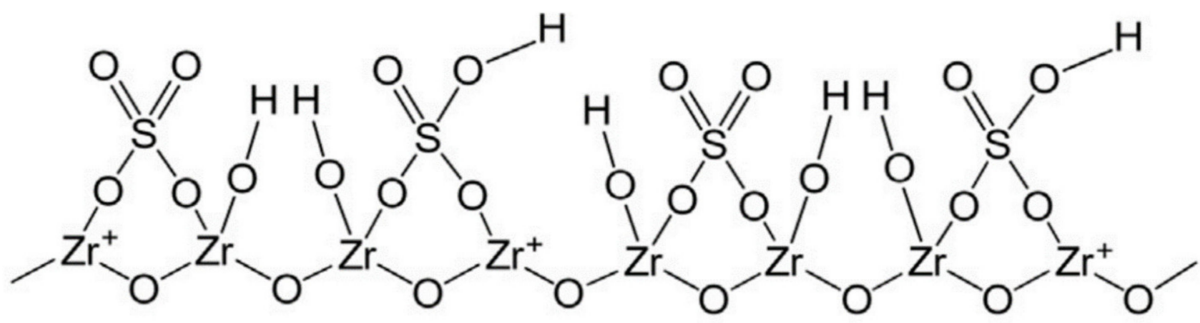

Figure 3. $\mathrm{ZrO}_{2}-\mathrm{SO}_{4}$ surface model of bidentate chelate type. Reprinted from ref. [29].

\subsection{Functional Group Characterization for $\mathrm{ZrO}_{2}-\mathrm{SO}_{4}$}

Research conducted by Utami et al. [31] reported the preparation of sulfated zirconia catalysts with various $\mathrm{H}_{2} \mathrm{SO}_{4}$ concentrations and calcination temperatures. Figure 4 shows the same absorption peak at wave number $424-741 \mathrm{~cm}^{-1}$, indicating the $\mathrm{Zr}-\mathrm{O}-\mathrm{Zr}$ bond [32]. Absorptions at 3426-3449 and $1636 \mathrm{~cm}^{-1}$ refer to the $\mathrm{O}-\mathrm{H}$ stretching and bending vibrations of the water molecules adsorbed on the material [33]. In addition, according to Ore et al. [15], the broadband in the absorption region of $3400 \mathrm{~cm}^{-1}$ signifies the bridge between the hydroxyl group with two or three $\mathrm{Zr}$ atoms.
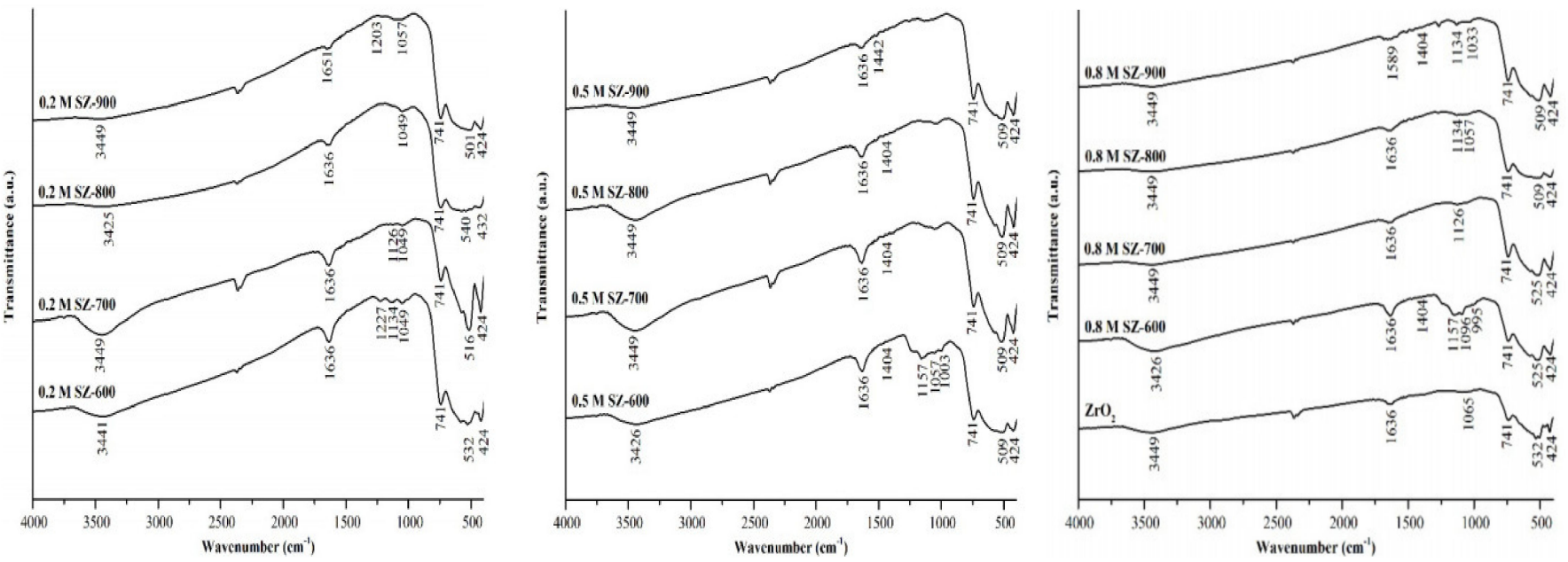

Figure 4. FTIR spectra of SZ catalyst at various sulfate concentrations and calcination temperatures. Reprinted with permission from Dr. Utami, Ref. [31]. Copyright 2019 Trans Tech Publication. 
The presence of $\mathrm{SO}_{4}{ }^{2-}$ ions on the surface of $\mathrm{ZrO}_{2}$ can be confirmed by the formation of a new peak at $995-1404 \mathrm{~cm}^{-1}$ which is typical of the bidentate $\mathrm{SO}_{4}{ }^{2-}$ chelate ion covalently bonded to the $\mathrm{Zr}^{4+}$ cation $[7,27]$. The absorption peaks at 995-1003, 1049-1096, 1134-1157, and $1227 \mathrm{~cm}^{-1}$ are $\mathrm{S}-\mathrm{O}$ symmetric vibrations, $\mathrm{S}-\mathrm{O}$ asymmetric vibrations, $\mathrm{S}=\mathrm{O}$ symmetry vibrations, and $\mathrm{S}=\mathrm{O}$ asymmetric vibrations [34-36]. The peak with low intensity in the area of $1404 \mathrm{~cm}^{-1}$ is the stretching vibration of $\mathrm{S}=\mathrm{O}$, indicating the formation of $\mathrm{SO}_{3}$ species on the surface of $\mathrm{ZrO}_{2}$ [37]. The presence of characteristic bands of $\mathrm{ZrO}_{2}-\mathrm{SO}_{4}$ proves that the impregnation of $\mathrm{H}_{2} \mathrm{SO}_{4}$ on $\mathrm{ZrO}_{2}$ has been successfully carried out.

The use of too high a concentration of $\mathrm{H}_{2} \mathrm{SO}_{4}$ can lead to loss of several absorption bands of the $\mathrm{SO}_{4}{ }^{2-}$ ion which is covalently bonded to $\mathrm{Zr}^{4+}$ cations as the $\mathrm{ZrO}_{2}$ structure is degraded [9,37]. Such a case implies that an appropriate or optimum concentration of $\mathrm{H}_{2} \mathrm{SO}_{4}$ is needed for the $\mathrm{ZrO}_{2}$ activation process. The absorption intensity of $\mathrm{ZrO}_{2}-\mathrm{SO}_{4}$ increased at a temperature range of $500-600{ }^{\circ} \mathrm{C}$ but decreased at temperatures of $700-800{ }^{\circ} \mathrm{C}$. Calcination treatment at $600{ }^{\circ} \mathrm{C}$ (SZ-0.8-600) was found to be optimum resulting in the highest $\mathrm{SO}_{4}{ }^{2-}$ dispersion. According to Ore [15], the maximum calcination temperature in the sulfation process is $650{ }^{\circ} \mathrm{C}$. Temperatures above $650{ }^{\circ} \mathrm{C}$ cause the decomposition of $\mathrm{SO}_{4}{ }^{2-}$ ions, thereby reducing the acidity and reactivity of the catalyst.

The acidity test of the catalyst was carried out by the gravimetric method based on the amount of $\mathrm{NH}_{3}$ vapor absorbed by the catalyst. Table 1 shows the results of the catalyst acidity test. $\mathrm{ZrO}_{2}$ has a total acidity of $0.18 \mathrm{mmol} / \mathrm{g}$. The acidity of $\mathrm{ZrO}_{2}$ comes from the $\mathrm{Zr}^{4+}$ cations that act as Lewis acid sites [7,8]. After modification with $\mathrm{H}_{2} \mathrm{SO}_{4}$, the acidity of $\mathrm{ZrO}_{2}$ increased. SZ-0.8-600 catalyst showed the highest acidity value of $1.06 \mathrm{mmol} / \mathrm{g}$. Ore et al. [15] reported that the number of Brønsted and Lewis acid sites depends on the $\mathrm{SO}_{4}{ }^{2-}$ concentration present on the catalyst surface. Sulfation with optimum sulfate concentration can increase the catalytic activity of the catalyst, while the decrease in catalyst acidity with increasing temperature occurs due to dehydration of protonic sites and loss of $\mathrm{SO}_{4}{ }^{2-}$ groups on the surface of the catalyst [38-40].

Table 1. Acidity test for the SZ catalyst at various sulfate concentrations and calcination temperatures [31].

\begin{tabular}{ccccc}
\hline & \multicolumn{5}{c}{ Acidity (mmol/g) } \\
\cline { 2 - 5 } Catalyst & $\mathbf{6 0 0}{ }^{\circ} \mathbf{C}$ & $\mathbf{7 0 0}{ }^{\circ} \mathbf{C}$ & $\mathbf{8 0 0}{ }^{\circ} \mathbf{C}$ & $\mathbf{9 0 0}{ }^{\circ} \mathbf{C}$ \\
\hline $\mathrm{ZrO}_{2}$ & 0.18 & - & - & - \\
$\mathrm{SZ}-0.2$ & 0.39 & 0.32 & 0.29 & 0.26 \\
$\mathrm{SZ}-0.5$ & 0.83 & 0.33 & 0.30 & 0.28 \\
$\mathrm{SZ}-0.8$ & 1.06 & 0.56 & 0.53 & 0.33 \\
\hline
\end{tabular}

Qualitatively, the number of Brønsted and Lewis acid sites can be observed absorption spectra intensity that denotes the interaction between the catalyst acid sites and $\mathrm{NH}_{3}$ [41]. Figure 5 presents the FTIR spectra of the catalyst after the acidity test. The absorption peak at 1119-1126 cm $\mathrm{cm}^{-1}$ indicates the presence of $\mathrm{NH}_{3}$ coordinated to the Lewis acid site. The peak at $1404 \mathrm{~cm}^{-1}$ confirmed the presence of $\mathrm{NH}^{4+}$ ions formed by proton transfer from the Brønsted acid site to $\mathrm{NH}_{3}[42,43]$. The higher the intensity of the absorption band, the higher the number of Brønsted and Lewis acid sites. It was found that the SZ-0.8-600 catalyst had the highest acid site intensities. The absorption intensities of the acid sites decreased with the increase in calcination temperature. Calcination treatment at high temperature decreases the acidity of the catalyst due to the decrease in the number of acid sites on the surface of the catalyst $[44,45]$. 

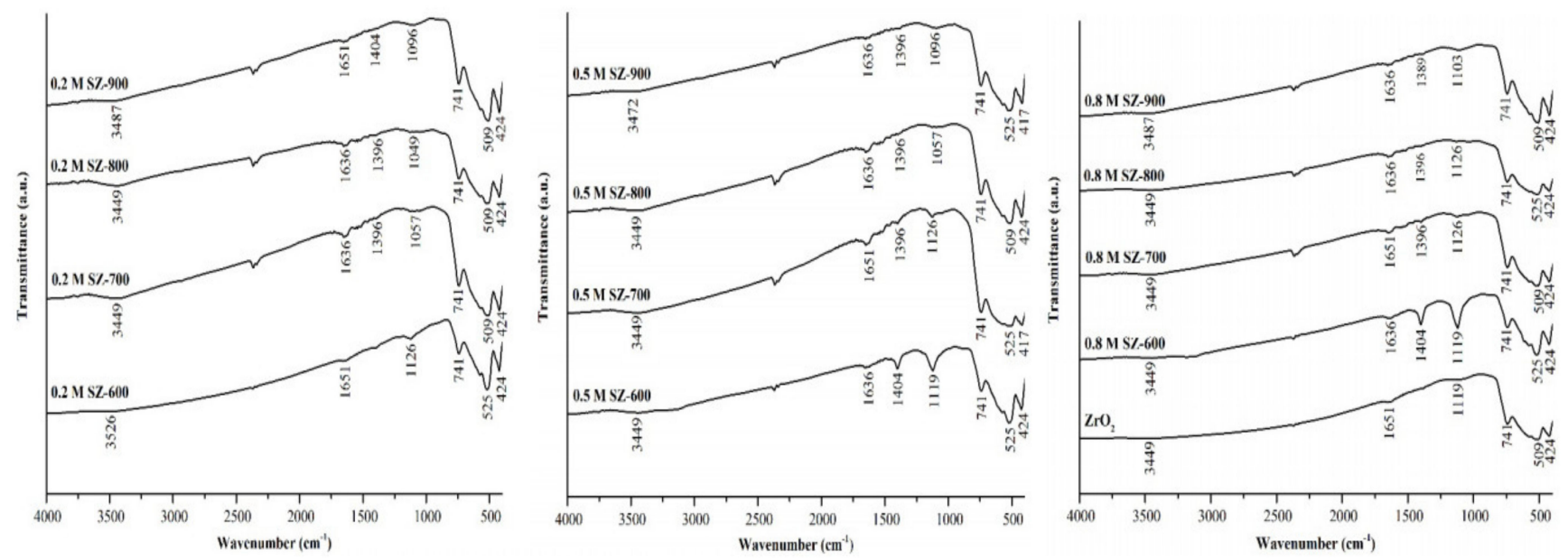

Figure 5. FTIR spectra of SZ catalyst at various sulfate concentrations and calcination temperatures after acidity test. Reprinted with permission from Dr. Utami, Ref. [31]. Copyright 2019 Trans Tech Publication.

\section{2. $\mathrm{ZrO}_{2}-\mathrm{SO}_{4}$ Crystal Structure Characterization}

Figure 6 presents the diffraction pattern of the SZ catalyst at various sulfate concentrations and calcination temperatures. The main diffraction peaks appear at $2 \theta=28.34^{\circ}$ (d-111) and $31.64^{\circ}$ (d111), referring to the $\mathrm{ZrO}_{2}$ monoclinic crystalline phase [6,15]. In general, the diffraction pattern showed stable crystallinity even after the addition of acid and calcination treatment. However, the intensity of the $\mathrm{ZrO}_{2}$ monoclinic diffraction peak decreased after acid treatment. SZ-0.8-600 catalyst with the highest total acidity showed the lowest monoclinic peak intensity. The addition of a high concentration of $\mathrm{H}_{2} \mathrm{SO}_{4}$ causes a large number of $\mathrm{SO}_{4}{ }^{2-}$ ions to cover the surface of $\mathrm{ZrO}_{2}$, decreasing crystallinity $[37,38]$. The intensities of the monoclinic peaks at temperatures of 800 and $900{ }^{\circ} \mathrm{C}$ were higher than those at 600 and $700{ }^{\circ} \mathrm{C}$. This occurred because the high calcination temperature caused $\mathrm{SO}_{4}{ }^{2-}$ ions to decompose from the catalyst surface, increasing the crystallinity of the catalyst.
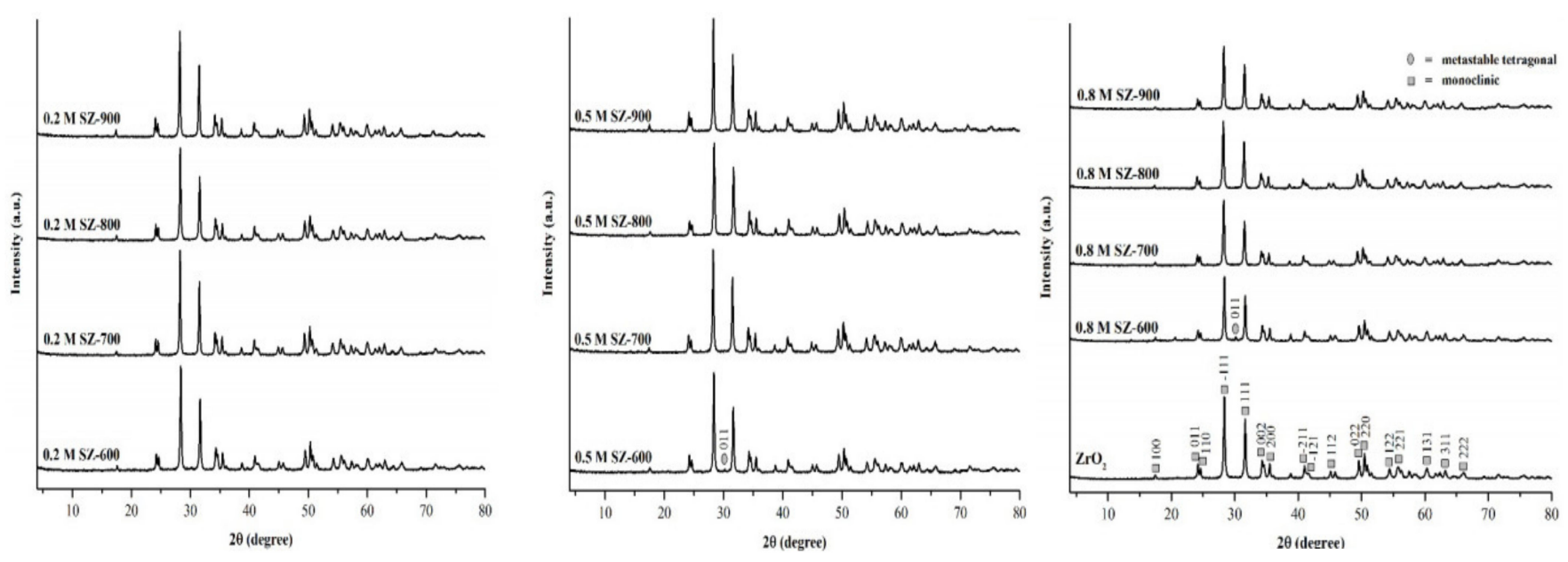

Figure 6. Diffraction patterns of SZ catalyst at various sulfate concentrations and calcination temperatures. Reprinted with permission from Dr. Utami, Ref. [31]. Copyright 2019 Trans Tech Publication.

$\mathrm{ZrO}_{2}-\mathrm{SO}_{4}$ calcined at a temperature of $<800{ }^{\circ} \mathrm{C}$ can exist in a metastable tetragonal phase and a monoclinic phase. Similar results were reported by Ore et al. [15] which stated that $\mathrm{ZrO}_{2}-\mathrm{SO}_{4}$ calcined at a temperature of $600{ }^{\circ} \mathrm{C}$ consists of a mixture of metastable tetragonal and monoclinic phases. The $\mathrm{ZrOCl}_{2} \cdot 8 \mathrm{H}_{2} \mathrm{O}$ amorphous precursor used made 
it possible for transformation to a metastable tetragonal structure to occur. However, the $\mathrm{ZrO}_{2}$ used in this study is commercial $\mathrm{ZrO}_{2}$, which contains the monoclinic structure of high stability and crystallinity, hindering it from undergoing phase transformation [46]. The catalyst diffraction pattern in the research by Utami et al. [6] demonstrated the $\mathrm{ZrO}_{2}$ catalyst and its modifications consisting only of monoclinic structure.

\section{Platinum/Sulfated Zirconia ( $\left.\mathrm{Pt} / \mathrm{ZrO}_{2}-\mathrm{SO}_{4}\right)$ Catalyst}

A heterogeneous catalyst is a catalyst material composed of two components, namely the doping and carrier components. The metal catalyst, when used in its pure form, has low thermal stability and tends to sinter that can leading to a decrease in surface area and deactivation [47-49]. Appropriate distribution of metal catalysts on the carrier material having acid-base sites and a large surface area is necessary to avoid sintering [50,51]. The $\mathrm{ZrO}_{2}-\mathrm{SO}_{4}$ material has many Brønsted and Lewis acid sites in which, despite its high acidity, this catalyst can be rapidly deactivated. The addition of $\mathrm{Pt}$ metal can increase the stability of the catalyst with the simultaneous presence of hydrogen gas $\left(\mathrm{H}_{2}\right)$ [52-54].

The distribution mechanism of $\mathrm{H}_{2}$ through the Pt surface on the $\mathrm{ZrO}_{2}-\mathrm{SO}_{4}$ carrier is illustrated in Figure 7. The $\mathrm{H}_{2}$ molecule dissociates on the surface of the Pt particle homolytically to form two $\mathrm{H}$ radicals which then bind to the unpaired electrons in the $5 \mathrm{~d}$ orbitals. The $\mathrm{H}^{+}$ions released from $\mathrm{Pt}$ are distributed on the $\mathrm{ZrO}_{2}-\mathrm{SO}_{4}$ carrier and migrate to the electron-rich $\mathrm{O}$ atomic sites, forming Brønsted acid sites [55,56]. Figure 8 shows the physical appearance of $\mathrm{ZrO}_{2}-\mathrm{SO}_{4}$ catalyst which a white powder and after the impregnation with $\mathrm{Pt}$ metal as a $\mathrm{Pt} / \mathrm{ZrO}_{2}-\mathrm{SO}_{4}$ catalyst, solid powder which is darker in color is formed due to the presence of the Pt metal that impregnated to the $\mathrm{ZrO}_{2}-\mathrm{SO}_{4}$ catalyst $[6,9]$.

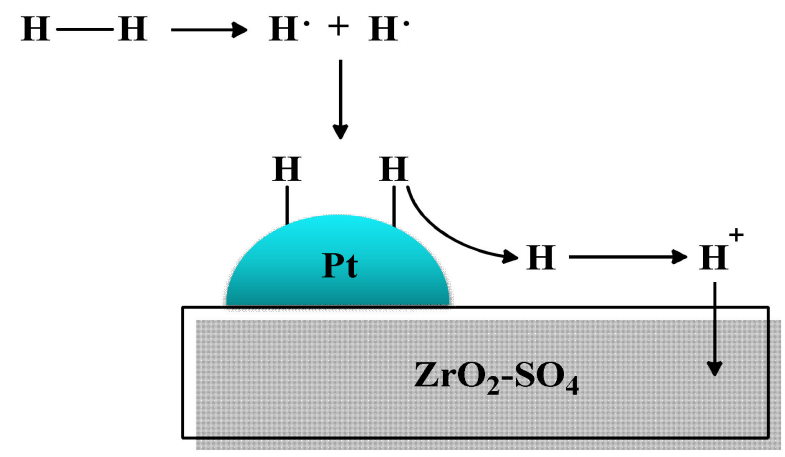

Figure 7. Mechanism of $\mathrm{H}_{2}$ distribution through the Pt surface on $\mathrm{ZrO}_{2}-\mathrm{SO}_{4}$. Reprinted and modified with permission from Dr. Utami, Ref. [9]. Copyright 2019 The Royal Society of Chemistry.

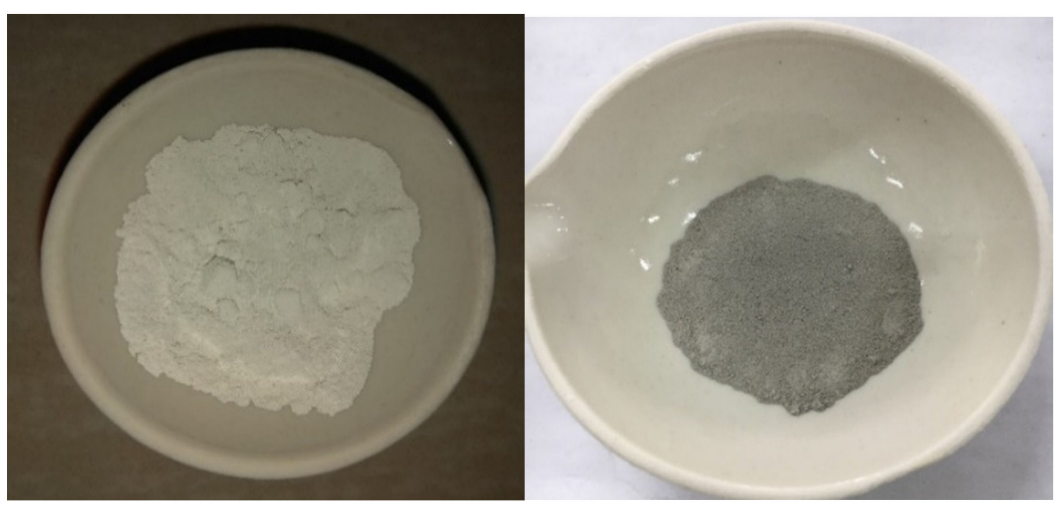

Figure 8. $\mathrm{ZrO}_{2}-\mathrm{SO}_{4}$ (right) and $\mathrm{Pt} / \mathrm{ZrO}_{2}-\mathrm{SO}_{4}$ (left) catalyst. Reprinted with permission from Dr. Utami, Ref. [42]. 


\subsection{FTIR and Acidity Characterization of Pt/ $\mathrm{ZrO}_{2}-\mathrm{SO}_{4}$ Catalyst}

Utami et al. [6] researched the synthesis of Pt-promoted zirconia (Pt/SZ) catalyst and its application in hydrocracking LDPE plastic into liquid fuel. The FTIR spectra of the sulfated zirconia impregnated with Pt metal can be seen in Figure 9. Overall, the Pt1/SZ, Pt2/SZ, and Pt3/SZ spectra showed the same absorption peaks as $\mathrm{ZrO}_{2}$ and $\mathrm{SZ}$. Pt metal impregnated catalysts had characteristic peaks of $\mathrm{ZrO}_{2}-\mathrm{SO}_{4}$ at wave number $1065-1126 \mathrm{~cm}^{-1}$. The addition of $\mathrm{Pt}$ metal caused some of the absorption peaks of $\mathrm{ZrO}_{2}-\mathrm{SO}_{4}$ to disappear. This is an early indication that $\mathrm{Pt}$ metal had been impregnated on nanoSZ [9].

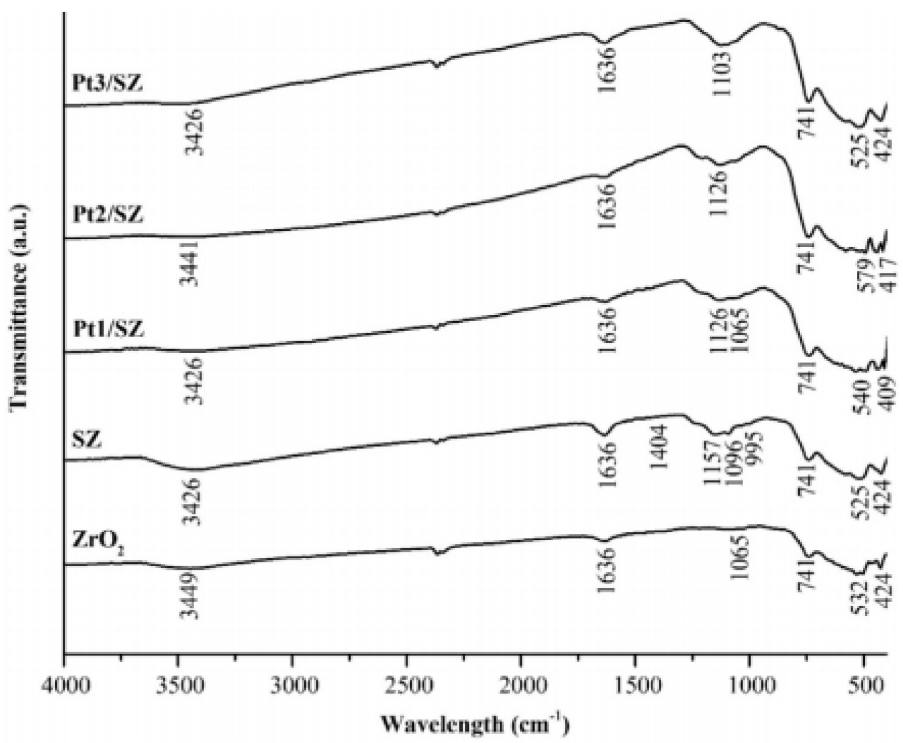

Figure 9. FTIR spectra of $\mathrm{ZrO}_{2}, \mathrm{SZ}, \mathrm{Pt} 1 / \mathrm{SZ}, \mathrm{Pt} 2 / \mathrm{SZ}$, and Pt3/SZ. Reprinted with permission from Dr. Utami, Ref. [6]. Copyright 2019 Elsevier.

Table 2 shows the total acidity of the catalysts of the present study. Pt metal impregnation on sulfated zirconia was proven to increase the total acidity of the catalyst significantly (from 1.06 to $10.75 \mathrm{mmol} / \mathrm{g}$ ). Pt1/SZ, Pt2/SZ, and Pt3/SZ catalysts showed increasing acidity values with increasing concentrations of Pt metal. The increase in the acidity of the catalyst occurs because the Pt metal provides vacant orbitals that can act as electron-pair acceptors (Lewis acid sites) and the presence of unpaired electrons in the $\mathrm{d}$ orbitals that form Brønsted acid sites [57,58].

Table 2. Acidity test results of $\mathrm{ZrO}_{2}, \mathrm{SZ}, \mathrm{Pt} 1 / \mathrm{SZ}, \mathrm{Pt} 2 / \mathrm{SZ}$, and Pt3/SZ [6].

\begin{tabular}{cc}
\hline Sample & Acidity (mmol/g) \\
\hline $\mathrm{ZrO}_{2}$ & 0.18 \\
$\mathrm{SZ}$ & 1.06 \\
$\mathrm{Pt} 1 / \mathrm{SZ}$ & 10.75 \\
$\mathrm{Pt} 2 / \mathrm{SZ}$ & 11.05 \\
$\mathrm{Pt} 3 / \mathrm{SZ}$ & 11.14 \\
\hline
\end{tabular}

FTIR spectra interpretations of $\mathrm{ZrO}_{2}, \mathrm{SZ}, \mathrm{Pt} 1 / \mathrm{SZ}, \mathrm{Pt} 2 / \mathrm{SZ}$, and $\mathrm{Pt} 3 / \mathrm{SZ}$ are shown in Figure 10. Increasing concentration of $\mathrm{Pt}$ metal produced increased adsorption of $\mathrm{NH}_{3}$ bound to the Brønsted and Lewis acid sites as shown at wavenumbers of 1396-1404 and $1119 \mathrm{~cm}^{-1}$, indicating that the higher the concentration of Pt metal, the higher the number of acid sites contained in the catalyst. The Pt3/SZ catalyst showed the highest intensity of Brønsted and Lewis acid absorptions. Based on the results of the acidity test of the catalyst, the Pt3/SZ catalyst was confirmed to have the highest acidity value. 


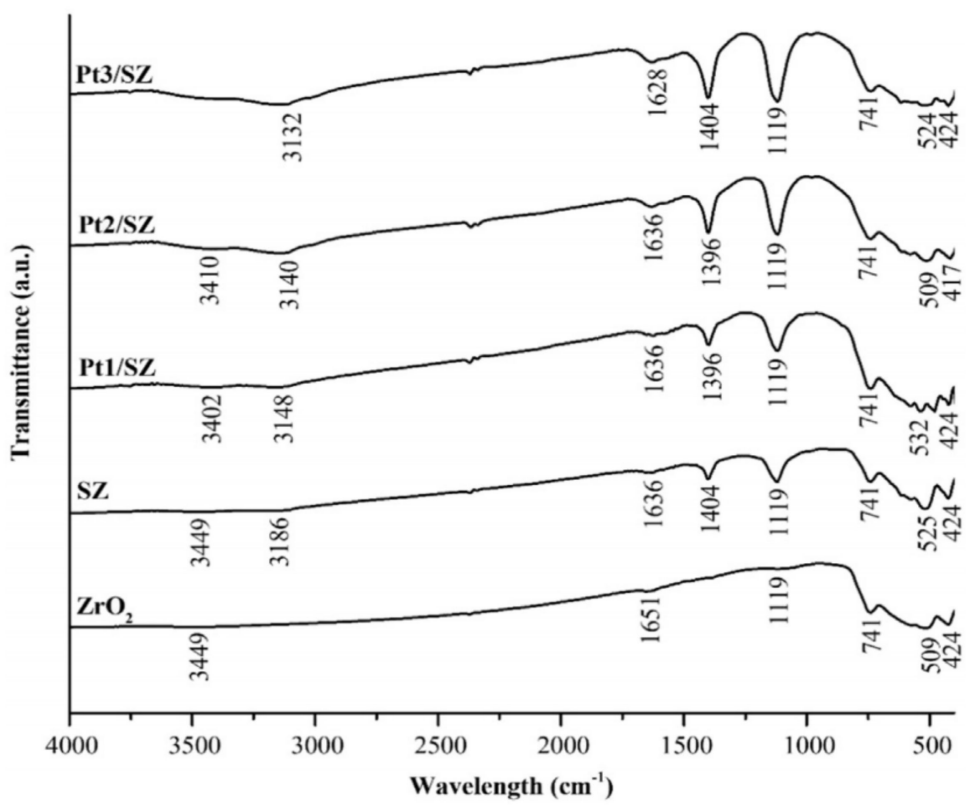

Figure 10. FTIR spectra of $\mathrm{ZrO}_{2}, \mathrm{SZ}, \mathrm{Pt} 1 / \mathrm{SZ}, \mathrm{Pt} 2 / \mathrm{SZ}$, and $\mathrm{Pt} 3 / \mathrm{SZ}$ after acidity test. Reprinted with permission from Dr. Utami, Ref. [6]. Copyright 2019 Elsevier.

\subsection{XRD and GSA Characterizations of $\mathrm{Pt} / \mathrm{ZrO}_{2}-\mathrm{SO}_{4}$ Catalyst}

SZ catalysts are shown in Figure 11. Based on crystal identification, all samples showed the presence of the monoclinic phase. According to Ore [15], $\mathrm{SO}_{4}{ }^{2-}$ species can be thermally crystallized through the calcination process and undergo a crystalline phase transformation, further stabilizing the $\mathrm{ZrO}_{2}$ crystalline phase. The addition of $\mathrm{Pt}$ metal to $\mathrm{SZ}$ would not have caused changes in the crystal structure of the material. A decrease in the intensity of the diffraction peak after the addition of Pt metal was observed. This phenomenon indicated that Pt metal had been successfully impregnated on the SZ surface, where a higher concentration of the impregnated Pt metal would cause the intensity of the monoclinic peak to decrease $[6,9]$.

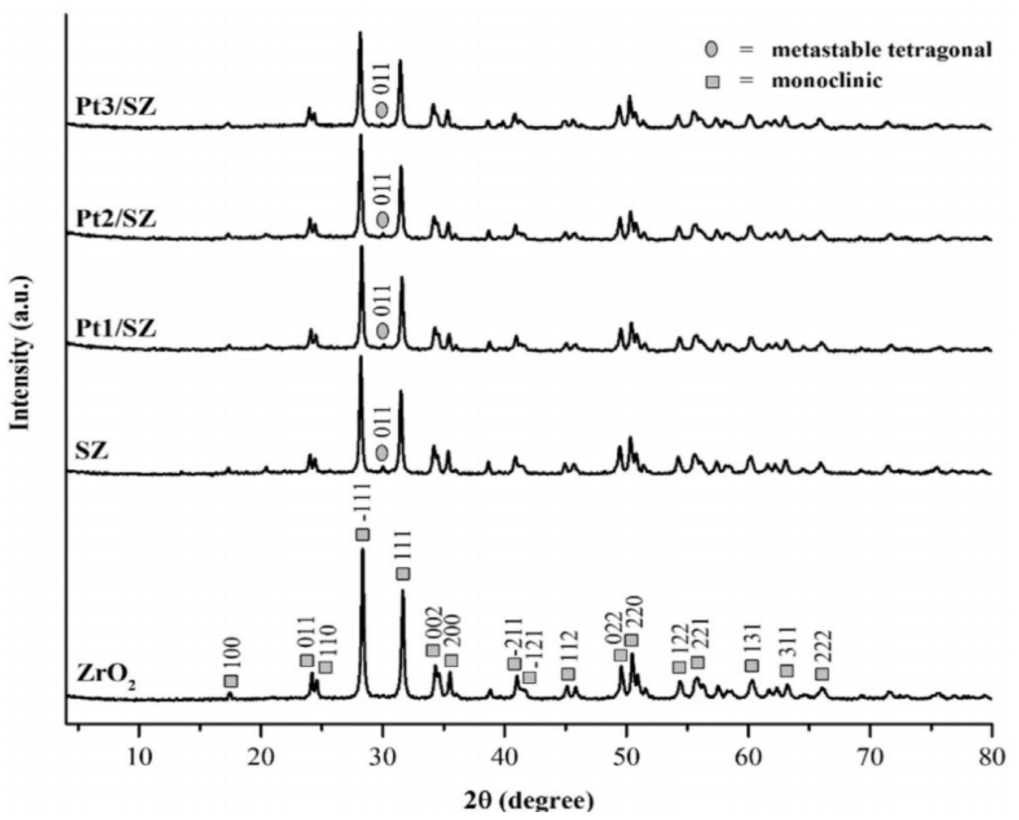

Figure 11. Diffraction patterns of $\mathrm{ZrO}_{2}, \mathrm{SZ}, \mathrm{Pt} 1 / \mathrm{SZ}, \mathrm{Pt} 2 / \mathrm{SZ}$, and Pt3/SZ. Reprinted with permission from Dr. Utami, Ref. [6]. Copyright 2019 Elsevier. 
Based on the catalyst diffraction pattern, Pt metal characteristic peaks were not detected. This is because the concentration of impregnated $\mathrm{Pt}$ metal was relatively low. This is by research conducted by Aboul-Gheit et al. [59] that showed similar results whereby the diffraction peak of $\mathrm{Pt}$ metal was not identified after the addition of $0.6 \% \mathrm{Pt}$ metal to $\mathrm{ZrO}_{2}-\mathrm{SO}_{4}$. A relatively low concentration of $\mathrm{Pt}$ metal was used in the present study to prevent agglomeration of $\mathrm{Pt}$ particles on the $\mathrm{ZrO}_{2}-\mathrm{SO}_{4}$ surface, which could cause a decrease in catalytic activity.

Characterization carried out by GSA (Table 3) showed an increase in surface area and pore volume along with the increasing concentration of Pt metal impregnated onto SZ. The $\mathrm{Pt} 1 / \mathrm{SZ}$ catalyst had a surface area and pore volume of $13.49 \mathrm{~m}^{2} / \mathrm{g}$ and $0.05 \mathrm{~cm}^{3} / \mathrm{g}$, respectively, which saw an increase to $20.23 \mathrm{~m}^{2} / \mathrm{g}$ and $0.06 \mathrm{~cm}^{3} / \mathrm{g}$ for Pt2/SZ and $29.48 \mathrm{~m}^{2} / \mathrm{g}$ and $0.08 \mathrm{~cm}^{3} / \mathrm{g}$ for Pt3/SZ. Based on the data reported in the study by Utami et al. [9], the increase in the surface area and pore volume of the SZ catalyst can be attributed to the inhibition of the agglomeration process related to the high presence of Pt metal.

Table 3. Textural characteristics of $\mathrm{ZrO}_{2}, \mathrm{SZ}, \mathrm{Pt} 1 / \mathrm{SZ}, \mathrm{Pt} 2 / \mathrm{SZ}$, and Pt3/SZ [6].

\begin{tabular}{|c|c|c|c|}
\hline Sample & Surface Area $\left(\mathrm{m}^{2} / \mathrm{g}\right)$ & Pore Volume $\left(\mathrm{cm}^{3} / \mathrm{g}\right)$ & Pore Diameter (nm) \\
\hline $\mathrm{ZrO}_{2}$ & 22.05 & 0.08 & 3.49 \\
\hline $\mathrm{SZ}$ & 12.49 & 0.05 & 3.82 \\
\hline $\mathrm{Pt} 1 / \mathrm{SZ}$ & 13.49 & 0.05 & 3.83 \\
\hline $\mathrm{Pt} 2 / \mathrm{SZ}$ & 20.23 & 0.06 & 3.84 \\
\hline $\mathrm{Pt} 3 / \mathrm{SZ}$ & 29.48 & 0.08 & 3.86 \\
\hline
\end{tabular}

The increase in the surface area of the catalyst can also be attributed to the smaller crystal size dimensions. Crystal size results of $\mathrm{ZrO}_{2}, \mathrm{SZ}, \mathrm{Pt} 1 / \mathrm{SZ}, \mathrm{Pt} 2 / \mathrm{SZ}$, and Pt3/SZ (Table 4) presented a decrease in size after metal impregnation of Pt. This indicated that the $\mathrm{Pt}$ metal impregnated by the reflux technique was evenly dispersed on the surface and pores of SZ [9]. In contrast, Aboul-Gheit et al. [59] impregnated Pt metal on $\mathrm{ZrO}_{2}-\mathrm{SO}_{4}$ through the wet impregnation method and reported an increase in the concentration of $\mathrm{Pt}$ metal causing the surface area and pore volume to increase due to the Pt metal being not evenly distributed and covering most of the $\mathrm{ZrO}_{2}-\mathrm{SO}_{4}$ pores.

Table 4. Crystal sizes of $\mathrm{ZrO}_{2}$, SZ, Pt1/SZ, Pt3/SZ Pt2/SZ and Pt3/SZ [6].

\begin{tabular}{cc}
\hline Sample & Crystal Size (nm) \\
\hline $\mathrm{ZrO}_{2}$ & 31.54 \\
$\mathrm{SZ}$ & 34.06 \\
$\mathrm{Pt} 1 / \mathrm{SZ}$ & 32.80 \\
$\mathrm{Pt} 2 / \mathrm{SZ}$ & 31.54 \\
$\mathrm{Pt} 3 / \mathrm{SZ}$ & 31.53 \\
\hline
\end{tabular}

\subsection{Elemental Composition Characterization Using EDXRF}

Table 5 shows the concentrations of elements contained in the catalysts. The concentrations of Pt metals identified in the Pt1/SZ, Pt2/SZ, and Pt3/SZ samples were 0.35, 0.90, and $1.19 \%$. The metal content of $\mathrm{Pt}$ in SZ was strongly influenced by the dispersion ability on the surface and pores of the carrier material. The reduction treatment with $\mathrm{H}_{2}$ gas flow was carried out after the calcination step which aimed to obtain $\mathrm{Pt}^{0}$ particles that would result in dispersion [14]. 
Table 5. Elemental compositions of $\mathrm{ZrO}_{2}, \mathrm{SZ}, \mathrm{Pt} 1 / \mathrm{SZ}, \mathrm{Pt} 2 / \mathrm{SZ}$ dan Pt3/SZ [6].

\begin{tabular}{ccccc}
\hline \multirow{2}{*}{ Sample } & \multicolumn{4}{c}{ Elemental Compositions $(\%$ w/w) } \\
\cline { 2 - 5 } & $\mathbf{Z r}$ & $\mathbf{P t}$ & $\mathbf{O}$ & $\mathbf{S}$ \\
\hline $\mathrm{ZrO}_{2}$ & 64.08 & - & 35.46 & 0.46 \\
$\mathrm{SZ}$ & 60.51 & - & 37.42 & 2.07 \\
$\mathrm{Pt} 1 / \mathrm{SZ}$ & 75.24 & 0.35 & 24.02 & 0.74 \\
$\mathrm{Pt} 2 / \mathrm{SZ}$ & 74.37 & 0.90 & 25.02 & 0.61 \\
$\mathrm{Pt} 3 / \mathrm{SZ}$ & 75.34 & 1.19 & 24.40 & 0.26 \\
\hline
\end{tabular}

Based on the elemental compositions above, the concentrations of Pt that were observed were lower than the theoretical concentration of $\mathrm{Pt}$ metal by the addition of $\mathrm{PtCl}_{4}$ solution used in the impregnation process. This discrepancy occurred due to competition between impregnated Pt metals, causing the formation of multilayer stacking of the active metal in the pore mouth area of the carrier material [60,61]. The active Pt metal that sat at the top position would have weak interaction and would experience easier desorption [62]. Because of this, the amount of active metal in the pore area of the carrier material was observed to be less.

\subsection{Pt metal Composition Identification Using XPS}

Subsequent research related to the synthesis of platinum-loaded sulfated zirconia catalysts using the hydrothermal method was reported by Utami et al. [9]. XPS spectra were used to determine the composition of $\mathrm{Pt}$ in the samples based on a comparison of binding energy values. The peaks generated from XPS are not single peaks, so that deconvolution of the peaks was needed to identify the multiple peaks that made up each peak. Figure 12 presents the XPS spectra along with the deconvolution of $\mathrm{Pt} 4 \mathrm{f}$ peaks from $\mathrm{Pt} /$ nano $\mathrm{ZrO}_{2}-\mathrm{SO}_{4}$ consisting of $\mathrm{Pt}^{0} 4 f_{7 / 2}, \mathrm{Pt}^{0} 4 f_{5 / 2}$, and $\mathrm{Pt}^{2+} 4 f_{7 / 2}$. The spectra indicated the interaction of electrons between the Pt particles and the nanoZS surface. Table 6 shows the relative area of the deconvoluted peaks of $\mathrm{Pt}^{0} 4 f_{7 / 2}, \mathrm{Pt}^{0} 4 f_{5 / 2}$, and $\mathrm{Pt}^{2+} 4 f_{7 / 2}$ in the $\mathrm{Pt} /$ nano $\mathrm{ZrO}_{2}-\mathrm{SO}_{4}$ sample. The data obtained showed that the detected $\mathrm{Pt}^{0}$ composition was $81.82 \%$. The results indicated that the reduction treatment with $\mathrm{H}_{2}$ gas flow at the metal impregnation stage succeeded in forming $\mathrm{Pt}^{0}$ particles.
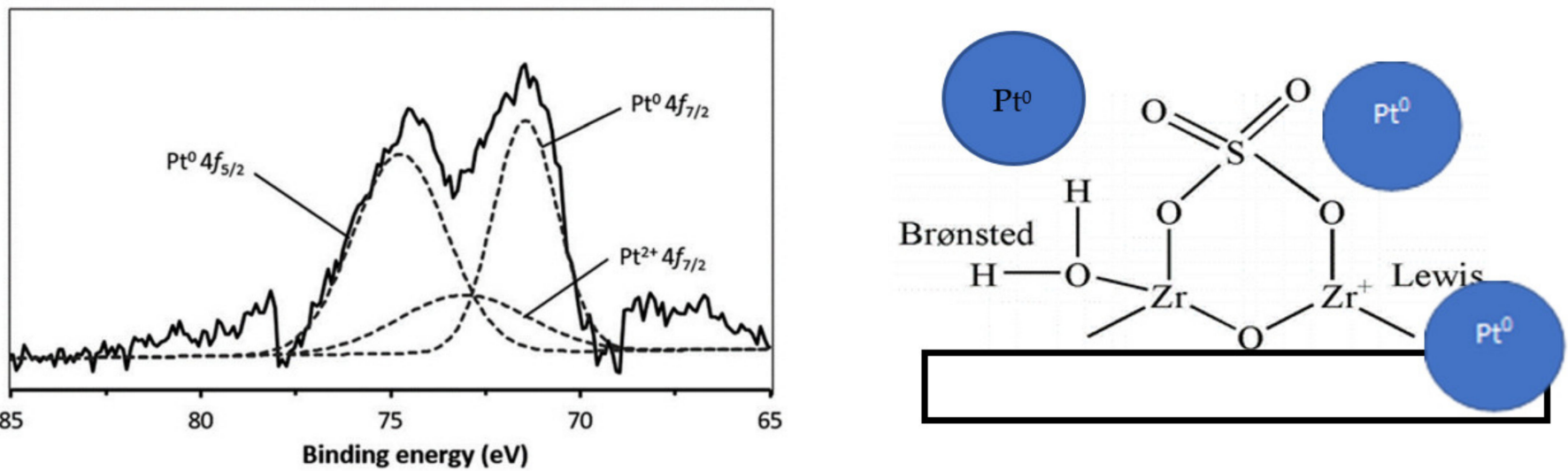

Figure 12. XPS spectra of $\mathrm{Pt} /$ nano $\mathrm{ZrO}_{2}-\mathrm{SO}_{4}$ in the $4 f$ region and the catalyst model. Reprinted and modified with permission from Dr. Utami, Ref. [9]. Copyright 2019 The Royal Society of Chemistry.

Table 6. Percentage of relative areas of $\mathrm{Pt} 4 f$ deconvoluted peaks [4].

\begin{tabular}{ccc}
\hline Pt $4 f$ Peak & Peak Position (eV) & Relative Area (\%) \\
\hline $\mathrm{Pt}^{0} 4 f_{7 / 2}$ & 71.45 & 36.36 \\
$\mathrm{Pt}^{0} 4 f_{5 / 2}$ & 74.75 & 45.46 \\
$\mathrm{Pt}^{2+} 4 f_{7 / 2}$ & 73.08 & 18.18 \\
\hline
\end{tabular}




\subsection{Thermal Stability Characterization with TG/DTA}

The TG/DTA curve provides information about changes in thermal conditions with mass changes in the sample. Figure 13 shows the TGA curves for nano $\mathrm{ZrO}_{2}$, nano $\mathrm{ZrO}_{2}-$ $\mathrm{SO}_{4}$, and $\mathrm{Pt} /$ nano $\mathrm{ZrO}_{2}-\mathrm{SO}_{4}$ samples analyzed at temperatures of $30-900{ }^{\circ} \mathrm{C}$. The TGA curve of nano $\mathrm{ZrO}_{2}$ did not indicate mass decrease indicating that nano $\mathrm{Z}$ had good thermal stability [63]. Mass decrease in nano $\mathrm{ZrO}_{2}-\mathrm{SO}_{4}$ and $\mathrm{Pt} /$ nano $\mathrm{ZrO}_{2}-\mathrm{SO}_{4}$ in the range of $50-200{ }^{\circ} \mathrm{C}$ by 2.41 and $1.24 \%$ were associated with the elimination of water molecules physically adsorbed on the material. At $500-700{ }^{\circ} \mathrm{C}$, decreases in a mass of 5.69 and $2.48 \%$, indicating the decomposition of $\mathrm{SO}_{4}{ }^{2-}$ ions bound to the $\mathrm{ZrO}_{2}$ surface. The decomposition of $\mathrm{SO}_{4}{ }^{2-}$ ions at $600-1000{ }^{\circ} \mathrm{C}$ affected the structural changes of $\mathrm{ZrO}_{2}-\mathrm{SO}_{4}$, causing a decrease in catalytic activity [64]. The decomposition of $\mathrm{H}_{2} \mathrm{SO}_{4}$ occurs through a two-stage endothermic process at high temperatures according to Equations (1) and (2).

$$
\begin{gathered}
\mathrm{H}_{2} \mathrm{SO}_{4}(\mathrm{aq}) \\
\mathrm{SO}_{3(\mathrm{~g})} \rightarrow \mathrm{H}_{2} \mathrm{O}_{2(\mathrm{l})}+\mathrm{SO}_{3}(\mathrm{~g}) \\
+\frac{1}{2} \mathrm{O}_{2}(\mathrm{~g})
\end{gathered}
$$

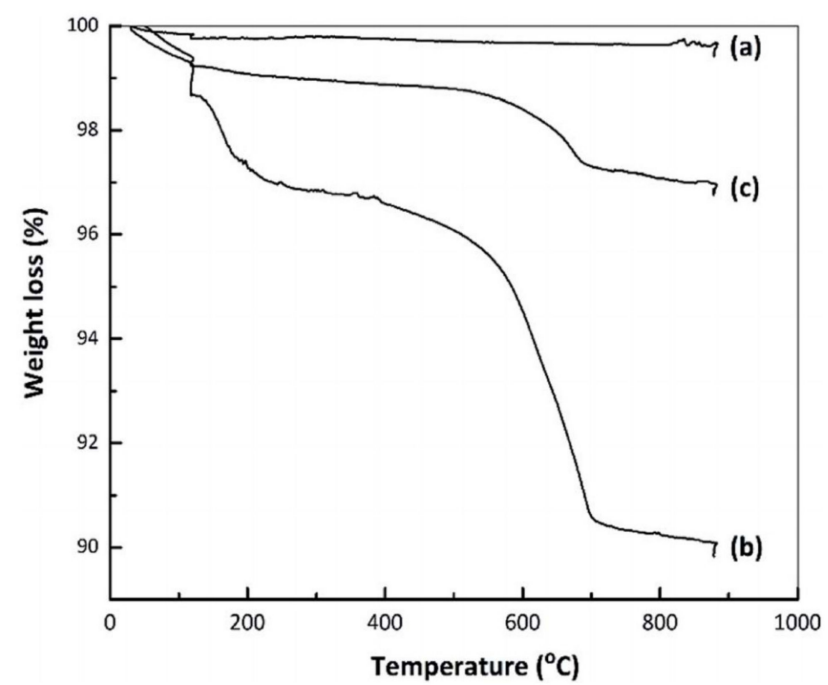

Figure 13. TGA curves of (a) nano $\mathrm{ZrO}_{2}$, (b) nano $\mathrm{ZrO}_{2}-\mathrm{SO}_{4}$, (c) $\mathrm{Pt} /$ nano $\mathrm{ZrO}_{2}-\mathrm{SO}_{4}$. Reprinted and modified with permission from Dr. Utami, Ref. [9]. Copyright 2019 The Royal Society of Chemistry.

\subsection{Activity and Selectivity of $\mathrm{Pt} / \mathrm{ZrO}_{2}-\mathrm{SO}_{4}$ Catalyst in LPDE Hydrocracking Application}

Utami et al. [6] reported the activity and selectivity of the $\mathrm{Pt} / \mathrm{ZrO}_{2}-\mathrm{SO}_{4}$ catalyst applied in LPDE hydrocracking. The hydrocracking liquid fraction of the LDPE plastic waste thermal cracking is shown in Figure 14. Physically, the hydrocracking liquid fraction has a yellow color and pungent odor, which indicate the success of the hydrocracking process. The percentages of liquid fractions produced using the Pt1/SZ, Pt2/SZ, and $\mathrm{Pt} 3 / \mathrm{SZ}$ catalysts were higher than that of the SZ catalyst. The percentage of liquid fraction obtained with the SZ catalyst was $57.92 \%$, while with Pt1/SZ, Pt2/SZ, and Pt3/SZ the liquid fractions were $70.58,71.15$, and $74.60 \%$, respectively. Through MS data, it was found that the hydrocarbon compounds in the gasoline range $\left(\mathrm{C}_{5}-\mathrm{C}_{12}\right)$ were more commonly found in the liquid fraction samples that had used Pt3/SZ (catalyst with the highest acidity). Table 7 shows the gasoline fraction percentages from the hydrocracking reaction using Pt1/SZ, $\mathrm{Pt} 2 / \mathrm{SZ}$, and Pt3/SZ catalysts, which were $48.76,64.22$, and $67.51 w / w \%$, respectively. This cased that besides affecting the amount of hydrocracking liquid fraction produced, the addition of Pt metal can also increase selectivity towards the gasoline fraction [65]. 


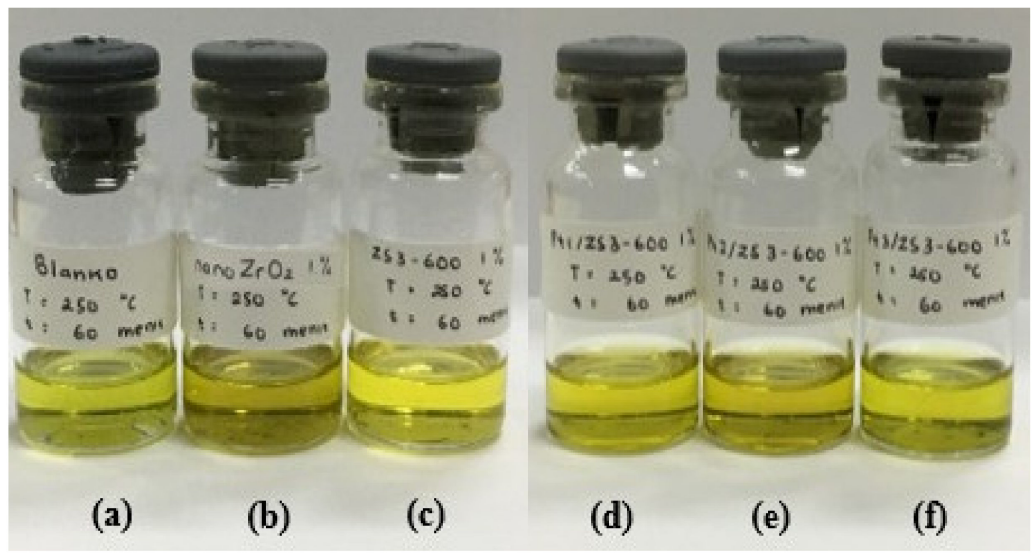

Figure 14. The physical appearance of the hydrocracking liquid fraction (a) without catalyst, and with catalyst (b) $\mathrm{ZrO}_{2}$, (c) SZ, (d) Pt1/SZ, (e) Pt2/SZ3, (f) Pt3/SZ. Reprinted with permission from Dr. Utami, Ref. [14].

Table 7. Distribution of hydrocracking products using different catalysts $\left(\mathrm{T}=250^{\circ} \mathrm{C}, \mathrm{t}=60 \mathrm{~m}\right.$, catalyst to feed ratio $=1 \% w / w)$ [6].

\begin{tabular}{|c|c|c|c|c|}
\hline \multirow{3}{*}{ Sample } & \multicolumn{4}{|c|}{ Hydrocracking Product ( $\% w / w)$} \\
\hline & \multicolumn{2}{|c|}{ Liquid } & \multirow[t]{2}{*}{ Solid } & \multirow[t]{2}{*}{ Gas } \\
\hline & $\mathrm{C}_{5}-\mathrm{C}_{12}$ & $\mathrm{C}_{13}-\mathrm{C}_{20}$ & & \\
\hline SZ & 42.95 & 14.97 & 0.35 & 41.73 \\
\hline Pt1/SZ & 48.76 & 21.82 & 0.15 & 29.27 \\
\hline $\mathrm{Pt} 2 / \mathrm{SZ}$ & 64.22 & 6.93 & 0.16 & 28.69 \\
\hline $\mathrm{Pt} 3 / \mathrm{SZ}$ & 67.51 & 7.09 & 0.15 & 25.25 \\
\hline
\end{tabular}

The percentage of hydrocarbon compounds in the $C_{5}-C_{12}$ range can be seen to be greater than that of $\mathrm{C}_{13}-\mathrm{C}_{20}$ hydrocarbons. This shows that the hydrocracking liquid fraction of LDPE plastic waste had a higher gasoline fraction than the diesel fraction and that the four types of catalysts used had good selectivity towards the hydrocracking reaction that produces liquid fuel fraction (gasoline fraction).

Figure 15 shows the proportion of hydrocarbon compounds contained in the hydrocracked liquid fraction in the gasoline range, namely olefins, paraffin, isoparaffins, and naphthenes, with a total composition of 56.36 and respective amounts of 20.07,14.60, and $6.81 \% w / w$ with use of the Pt3/SZ catalyst. Aromatic compounds in small amounts were also produced with a composition of $0.70 \% w / w$, and only $1.46 \% w / w$ was indicated to be non-hydrocarbon compounds. Overall, olefin (unsaturated/double-bonded compound) was dominantly produced from the hydrocracking. This is because LDPE, as the plastic feed used, consists of olefin in which, during the hydrocracking reaction, not all olefins react with the hydride to become paraffin (saturated/single bond compound) $[6,9]$.

\subsection{Stability Test of $\mathrm{Pt} / \mathrm{ZrO}_{2}-\mathrm{SO}_{4}$}

A stability test of the $\mathrm{Pt} /$ nano $\mathrm{ZrO}_{2}-\mathrm{SO}_{4}$ catalyst, along with nano $\mathrm{ZrO}_{2}$ and nano $\mathrm{ZrO}_{2}-\mathrm{SO}_{4}$ for comparison, was carried out by Utami et al. [9] through a hydrocracking reaction of LDPE plastic waste with a catalyst/feed ratio $1 \% w / w$ and a temperature of $250{ }^{\circ} \mathrm{C}$ for $60 \mathrm{~min}$. The catalyst stability test was carried out for six cycles with the same reaction conditions. Figure 16 shows that $\mathrm{ZrO}_{2}, \mathrm{SZ}$, and $\mathrm{Pt} 3 / \mathrm{SZ}$ had good catalytic performances when first used. The hydrocracking reaction with the $\mathrm{ZrO}_{2}$ catalyst showed a significant decrease in the percentage of liquid fraction produced in the fourth cycle, while in SZ this significant reduction occurred in the second cycle. 


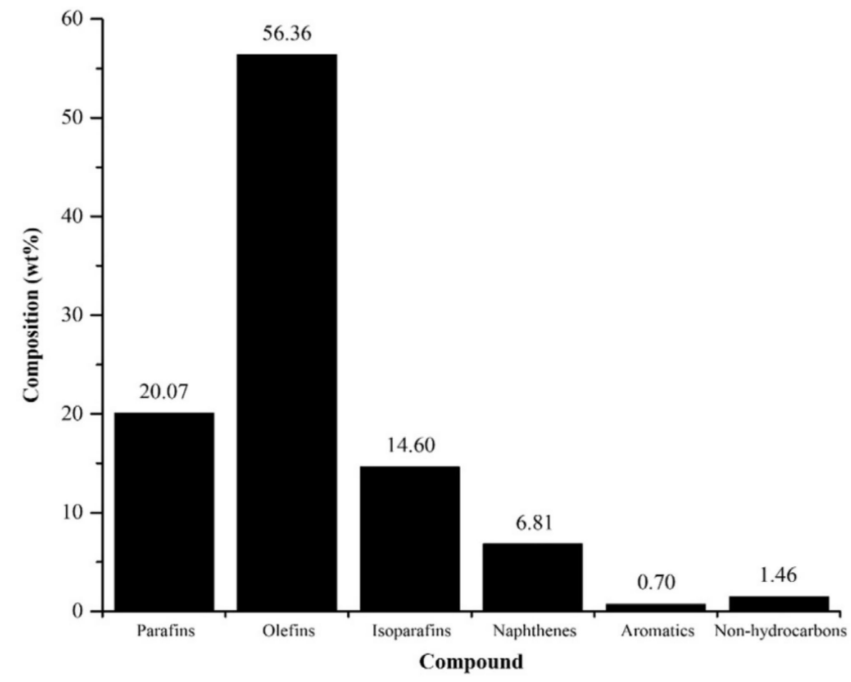

Figure 15. The composition of liquid yield in the gasoline fraction from the hydrocracking reaction of LDPE plastic waste using Pt3/SZ at $250{ }^{\circ} \mathrm{C}$. Reprinted with permission from Dr. Utami, Ref. [6]. Copyright 2019 Elsevier.

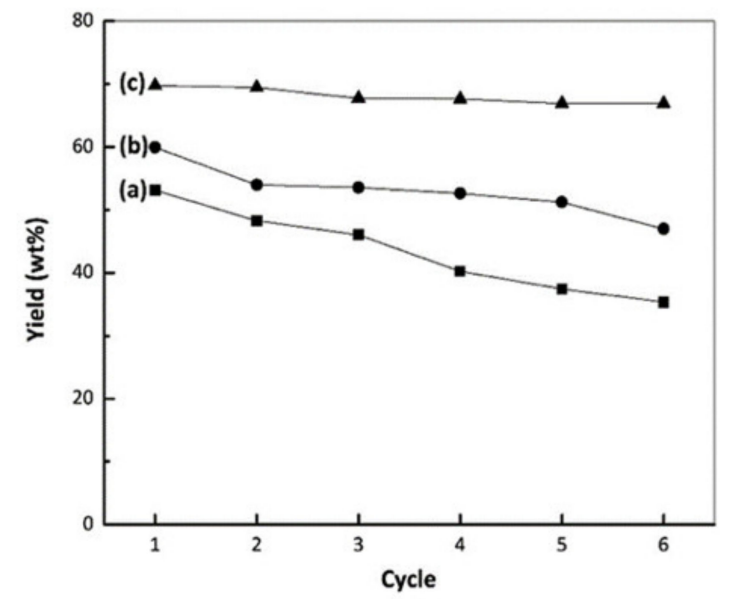

Figure 16. Hydrocracking liquid fraction graphs of (a) nano $\mathrm{ZrO}_{2}$, (b) nano $\mathrm{ZrO}_{2}-\mathrm{SO}_{4}$, and (c) $\mathrm{Pt} /$ nano ZS3 Pt/nanoZS3-600. Reprinted and modified with permission from Dr. Utami, Ref. [9]. Copyright 2019 The Royal Society of Chemistry.

The catalytic activity of Pt3/SZ showed very good stability up to the sixth cycle. Aboul-Gheit et al. [59] reported that the catalytic activity of $\mathrm{ZrO}_{2}-\mathrm{SO}_{4}$ in the n-pentane isomerization reaction decreased in the fourth cycle and became inactive in the eighth cycle. In contrast, the $\mathrm{Pt} / \mathrm{ZrO}_{2}-\mathrm{SO}_{4}$ catalyst showed stable activity until the tenth cycle. The $\mathrm{Pt} / \mathrm{ZrO}_{2}-\mathrm{SO}_{4}$ catalyst showed high resistance to the deactivation related to the removal of coke from the catalyst surface, thus increasing the stability of the catalyst [36,37].

Figure 16 illustrates the proposed origin of the catalytic stability of $\mathrm{ZrO}_{2}-\mathrm{SO}_{4}$ and Pt/nanoZS3-600 nanoscales. Based on the activity and catalytic selectivity data, the conversion of LDPE using nano $\mathrm{ZrO}_{2}-\mathrm{SO}_{4}$ produced the highest amount of coke. In addition, this material had a high initial activity but low resistance to the deactivation process as its catalytic properties decreased rapidly in its consequent cycle of use. The formation of a coke can causes the pores and the active sites of the catalyst to be closed and thus reduce activity [44], i.e., the deactivation process that occurred in the $\mathrm{ZrO}_{2}-\mathrm{SO}_{4}$ nanocatalyst would have been difficult to control. To restore the activity of nanoZS3-600, catalyst regeneration, i.e., coke removal, is indispensable, especially in large-scale industrial applications. Promisingly, the Pt/nanoZS3-600 catalyst showed good activity, selectivity, and stability even after repeated use. 


\section{5. $\mathrm{Cr} / \mathrm{ZrO}_{2}-\mathrm{SO}_{4}$ Catalyst}

The metals that are widely used for bifunctional catalysts are usually transition metals with have incomplete orbitals that function as Lewis acid sites. One of the said transition metals is chromium (Cr) [66]. Cr can be doped on a carrier to enhance the catalytic activity of the host $[67,68]$. The addition of $\mathrm{Cr}$ metal to sulfated zirconia can also increase the acidity of the catalyst as the metal would contribute to the presence of Lewis acid sites [69]. The presence of $\mathrm{Cr}$ metal on sulfated zirconia also affects increasing the surface area of the catalyst [70,71]. Figure 17 illustrates the reaction mechanism of sulfated zirconia impregnated with $\mathrm{Cr}$ metal when interacting with ammonia during an acidity test. Hauli et al. [71] stated that the addition of chromium metal to sulfated zirconia not only increases the surface area of the catalyst but also stabilizes pure zirconia at high calcination temperatures. Increased temperature can thus remove sulfate groups and damage the porosity of the structure, causing the catalyst to deactivate. The physical appearance of the $\mathrm{ZrO}_{2}-\mathrm{SO}_{4}$ and $\mathrm{Cr} / \mathrm{ZrO}_{2}-\mathrm{SO}_{4}$ catalyst (Figure 18) shows solid particle color change after the impregnation of $\mathrm{Cr}$ metal to the $\mathrm{ZrO}_{2}-\mathrm{SO}_{4}$ catalyst. The gray solid particle is formed due to the presence of Cr metal.

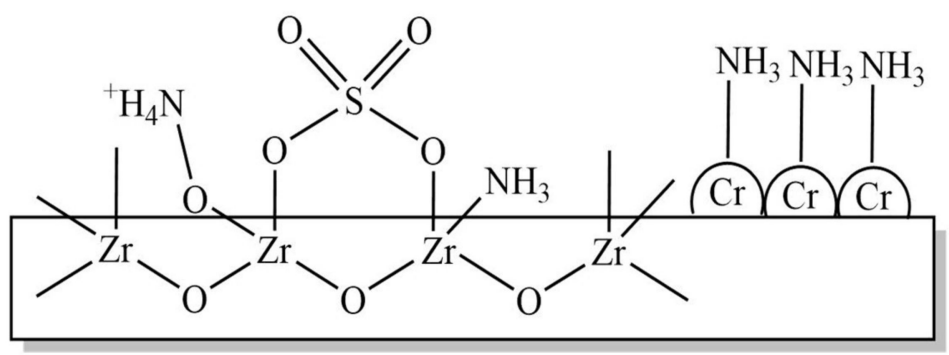

Figure 17. Proposed model of ammonia interaction on metal-embedded sulfated zirconia. Reprinted from Ref. [68]. Copyright Elsevier.

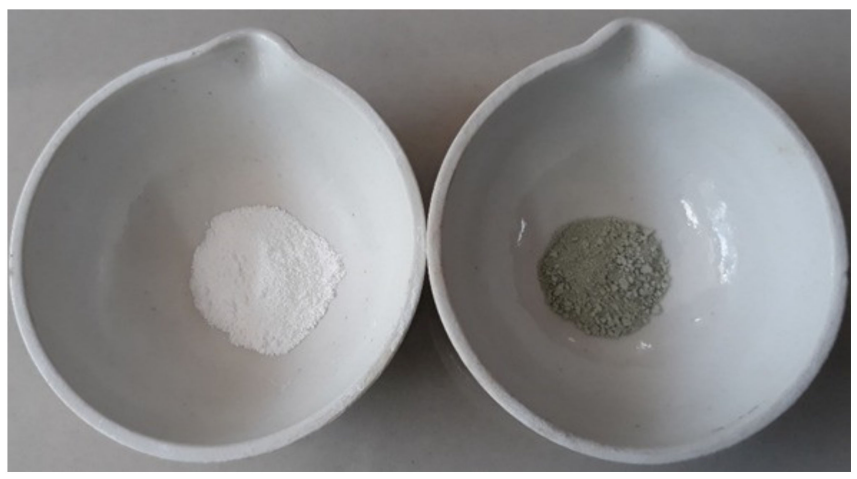

Figure 18. $\mathrm{ZrO}_{2}-\mathrm{SO}_{4}$ (left) and $\mathrm{Cr} / \mathrm{ZrO}_{2}-\mathrm{SO}_{4}$ (right) catalyst. Reprinted with permisission from Dr. Hauli, Ref. [71].

\subsection{FITR and Acidity Characterizations of $\mathrm{Cr} / \mathrm{ZrO}_{2}-\mathrm{SO}_{4}$ Catalyst}

Research on $\mathrm{Cr} / \mathrm{ZrO}_{2}-\mathrm{SO}_{4}$ catalyst has been reported by Hauli et al. [72]. FTIR results of $\mathrm{ZrO}_{2}, \mathrm{SZ}$ 0.8-600 (SZ), 0.5\% Cr/SZ (Cr1/SZ), $1.0 \% \mathrm{Cr} / \mathrm{SZ}$ (Cr2/SZ), and 1.5\% Cr/SZ (Cr3/SZ) are shown in Figure 19. The spectra showed no specific differences between the spectra of $\mathrm{Cr}$-embedded zirconia catalyst and sulfated zirconia. However, the specific absorption peak of the sulfate group at 1053-1224 $\mathrm{cm}^{-1}$, decreased with the presence of $\mathrm{Cr}$. This is because the heating process involved in the loading of the metal had allowed sulfates to be released from the $\mathrm{ZrO}_{2}$ surface. The presence of metal produced not sulfate decomposition but rather the release of the sulfate groups from the surface of $\mathrm{ZrO}_{2}$ during the heating process [72]. Hanifah et al. [38] reported similar phenomena, namely that the presence of monometals and bimetals on $\mathrm{ZrO}_{2}-\mathrm{SO}_{4}$ release of sulfate group materialized whilst its decomposition did not. 


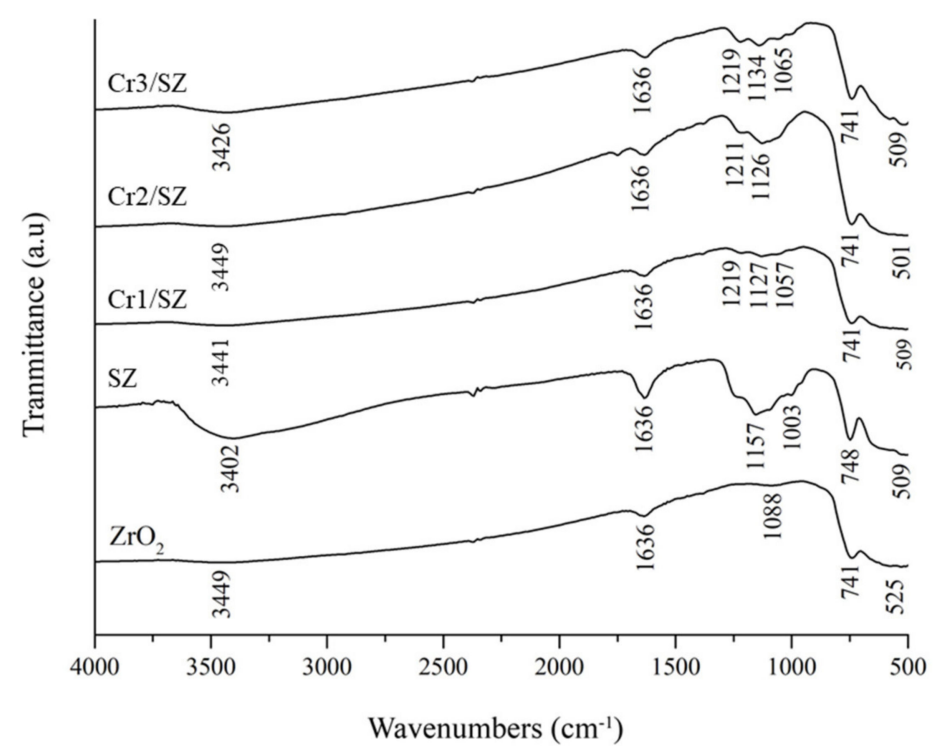

Figure 19. FTIR spectra of $\mathrm{ZrO}_{2}, \mathrm{SZ}, \mathrm{Cr} 1 / \mathrm{SZ}, \mathrm{Cr} 2 / \mathrm{SZ}, \mathrm{Cr} 3 / \mathrm{SZ}$. Reprinted with permission from Dr. Hauli, Ref. [72]. Copyright 2019 Trans Tech Publication.

The presence of empty orbitals in $\mathrm{Cr}$ metal allows electrons from other atoms to take their place in the orbital in what would then contribute to higher acidity of the $\mathrm{Cr}$ containing material. Acidity test results of $\mathrm{Cr}$-containing catalysts are presented in Table 8 confirming this. The acidity of the catalyst increased after the addition of $\mathrm{Cr}$ metal. The $\mathrm{Cr} 1 / \mathrm{SZ}$ catalyst was the catalyst with the highest acidity value with $8.22 \mathrm{mmol} / \mathrm{g}$. The low acidity value at high $\mathrm{Cr}$-metal concentration was caused by the presence of metal particle aggregates that had covered the active metal sites on the carrier material. The more $\mathrm{Cr}$ metal that was embedded, the greater the amount of metal not accommodated in the pores of the carrier material, leading to the formation of aggregates.

Table 8. Acidity values of the catalysts [72].

\begin{tabular}{cc}
\hline Sample & Acidity $(\mathbf{m m o l} / \mathbf{g})$ \\
\hline $\mathrm{SZ}$ & 3.81 \\
$\mathrm{Cr} 1 / \mathrm{SZ}$ & 6.24 \\
\hline $\mathrm{Cr} 2 / \mathrm{SZ}$ & 8.22 \\
\hline $\mathrm{Cr} 3 / \mathrm{SZ}$ & 6.75 \\
\hline
\end{tabular}

The acidity test of the catalyst was carried out to determine the total acidity value of each catalyst. The FTIR spectra after the acidity test results for the $\mathrm{ZrO}_{2}, \mathrm{SZ}, \mathrm{Cr} 1 / \mathrm{SZ}$, $\mathrm{Cr} 2 / \mathrm{SZ}$, and Cr3/SZ catalysts are shown in Figure 20. The results show the same absorption peaks at wave numbers 1119 and $1404 \mathrm{~cm}^{-1}$, confirming the presence of the Lewis and Brønsted acid sites on each catalyst. Cr-embedded sulfated zirconia catalyst showed a higher intensity of Lewis and Brønsted acid sites than before $\mathrm{Cr}$ metal was added. The spectra of the Cr/SZ catalyst had the highest acid site intensity, indicating that Cr2/SZ had a high acidity value. The results of the acidity test of the catalysts confirmed that $\mathrm{Cr} 2 / \mathrm{SZ}$ had the highest acidity value of $8.22 \mathrm{mmol} / \mathrm{g}$. 


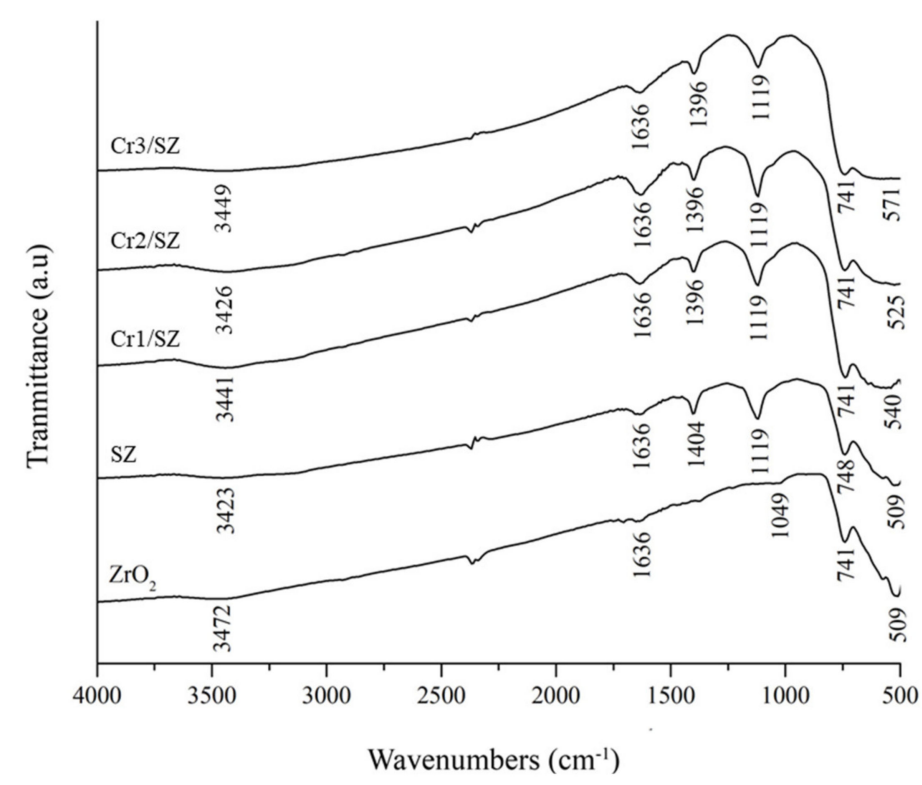

Figure 20. FTIR spectra of SZ, Cr1/SZ, Cr2/SZ, and Cr3/SZ after acidity test. Reprinted with permission from Dr. Hauli, Ref. [72]. Copyright 2019 Trans Tech Publication.

\subsection{XRD Characterization of $\mathrm{Cr} / \mathrm{ZrO}{ }_{2}-\mathrm{SO}_{4}$ Catalyst}

The diffraction patterns of $\mathrm{ZrO}_{2}, \mathrm{SZ}, \mathrm{Cr} 1 / \mathrm{SZ}, \mathrm{Cr} 2 / \mathrm{SZ}$, and $\mathrm{Cr} 3 / \mathrm{SZ}$ catalysts are presented in Figure 21. The bearing of $\mathrm{Cr}$ metal on sulfated zirconia provided no change in the crystal phase structure of $\mathrm{ZrO}_{2}$. The main peaks were found in the $2 \theta$ region around $28^{\circ}, 31^{\circ}$, and $50^{\circ}$ denoting plane distances of $\mathrm{d}_{-111}(3,2 \AA), \mathrm{d}_{111}(2,8 \AA), \mathrm{d}_{220}(1,8 \AA)$ with the highest intensity in the $28^{\circ}$ region. Sulfate and $\mathrm{Cr}$ impregnation on $\mathrm{ZrO}_{2}$ have a lower intensity peak than $\mathrm{ZrO}_{2}$. This is due to the presence of sulfate on $\mathrm{ZrO}_{2}$ and to $\mathrm{Cr}$ metal covering the surface of $\mathrm{SZ}$, inhibiting the growth of $\mathrm{ZrO}_{2}$ crystals and thereby decreasing the crystallinity of the materials $[73,74]$.

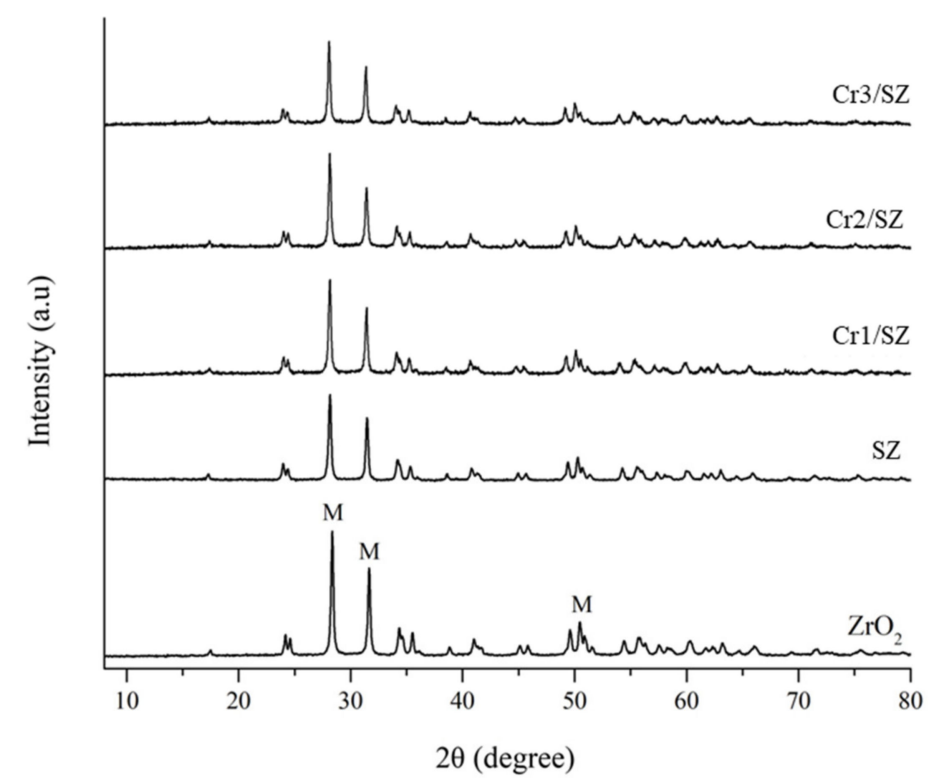

Figure 21. Diffraction patterns of $\mathrm{ZrO}_{2}, \mathrm{SZ}, \mathrm{Cr} 1 / \mathrm{SZ}, \mathrm{Cr} 2 / \mathrm{SZ}, \mathrm{Cr} 3 / \mathrm{SZ}$. Reprinted with permission from Dr. Hauli, Ref. [72]. Copyright 2019 Trans Tech Publication. 


\subsection{SAA Characterization of $\mathrm{Cr} / \mathrm{ZrO}_{2}-\mathrm{SO}_{4}$ Catalyst}

Characterization of pore characteristics including surface area, pore diameter, and pore volume was carried out by SAA analysis. The results of the SAA measurements of the catalysts are shown in Table 9. As can be seen, the addition of $\mathrm{Cr}$ metal to sulfated zirconia increased the surface area, pore diameter, and pore volume of the catalyst. This can be attributed to the uniform distribution of $\mathrm{Cr}$ metal on the catalyst surface $[69,70]$. The surface area of the catalyst, however, decreased upon the addition of higher concentrations of $\mathrm{Cr}$ metal, namely at $\mathrm{Cr} 3 / \mathrm{ZS}$, due to the entry of $\mathrm{Cr}$ metal into the catalyst pores causing agglomeration of metal atoms that covered the catalyst pores [74].

Table 9. Pore characteristics of the catalysts [72].

\begin{tabular}{cccc}
\hline Sample & Surface Area $\left(\mathbf{m}^{2} / \mathbf{g}\right)$ & Pore Diameter $(\mathbf{n m})$ & Pore Volume $\left(\mathbf{c m}^{3} / \mathbf{g}\right)$ \\
\hline $\mathrm{ZrO}_{2}$ & 12.27 & 3.70 & 0.07 \\
$\mathrm{SZ}$ & 7.79 & 3.68 & 0.08 \\
$\mathrm{Cr} 1 / \mathrm{SZ}$ & 12.62 & 3.70 & 0.12 \\
$\mathrm{Cr} 2 / \mathrm{SZ}$ & 14.56 & 3.70 & 0.08 \\
$\mathrm{Cr} 3 / \mathrm{SZ}$ & 11.91 & 9.04 & 0.04 \\
\hline
\end{tabular}

The adsorption and desorption isotherm patterns for $\mathrm{ZrO}_{2}, \mathrm{SZ}, \mathrm{Cr} 1 / \mathrm{SZ}, \mathrm{Cr} 2 / \mathrm{SZ}$, and $\mathrm{Cr} 3 / \mathrm{SZ}$ catalysts are shown in Figure 22. Based on the IUPAC classification, all catalysts showed a type IV isotherm pattern, which is characteristic of the isotherm pattern for mesoporous materials with pore diameter sizes of $2-50 \mathrm{~nm}$. The adsorption-desorption isotherm patterns of the $\mathrm{Cr} 1 / \mathrm{SZ}$ and $\mathrm{Cr} 2 / \mathrm{SZ}$ catalysts demonstrated monolayer absorption of nitrogen gas on the surface when $P / P_{0}<0.2$. At a relative pressure of $0.2<P / P_{0}<1$, the isotherm curve experienced a sharp increase in volume representing a multilayer arrangement. In the $\mathrm{Cr} 3 / \mathrm{SZ}$ catalyst, the absorption of a monolayer of nitrogen gas on the surface occurred when $P / P_{0}<0.4$ and experienced a sharp increase in volume at $0.4<P / P_{0}<1$. The $\mathrm{ZrO}_{2}, \mathrm{Cr} 2 / \mathrm{SZ}$, and $\mathrm{Cr} 3 / \mathrm{SZ}$ catalyst had a type $\mathrm{H} 4$ hysteresis, while $\mathrm{SZ}$ and $\mathrm{Cr} 1 / \mathrm{SZ}$ had type H3. Type $\mathrm{H} 3$ hysteresis showed no absorption limit at high $P / P_{0}$. Type $\mathrm{H} 4$ hysteresis is associated with narrow slit pores [4,72]. These three types of catalysts exhibit the characteristics of porous materials. This form of porous material is composed of aggregates of particles such as plates that form pore gaps [10].

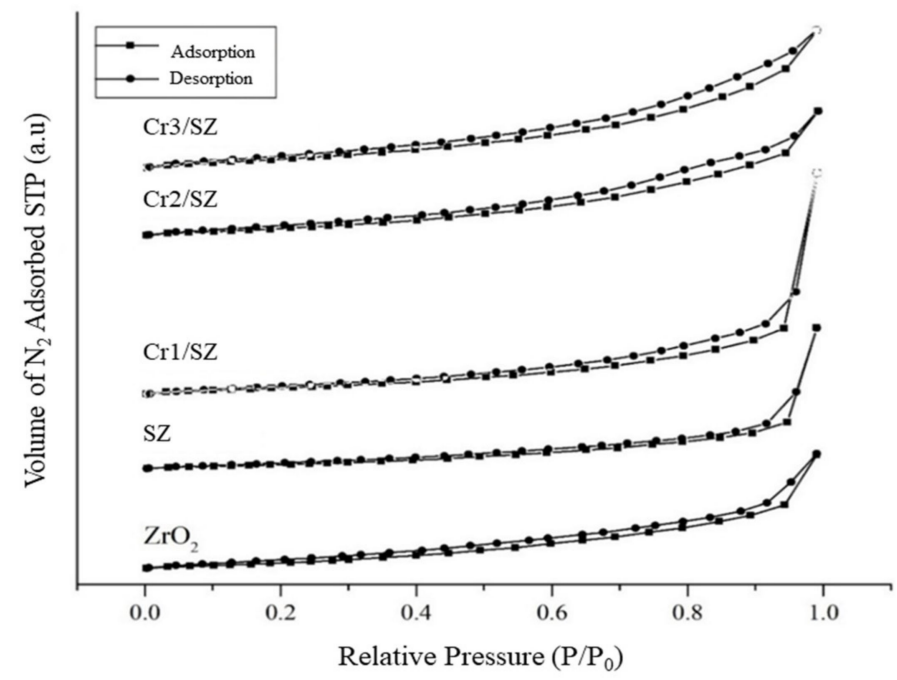

Figure 22. Adsorption desorption isotherm patterns of $\mathrm{ZrO}_{2}, \mathrm{SZ}, \mathrm{Cr} 1 / \mathrm{SZ}, \mathrm{Cr} 2 / \mathrm{SZ}$, and Cr3/SZ. Reprinted with permission from Dr. Hauli, Ref. [72]. Copyright 2019 Trans Tech Publication. 


\subsection{Activity and Selectivity Tests of $\mathrm{Cr} / \mathrm{ZrO}_{2}-\mathrm{SO}_{4}$ Catalyst}

A catalytic activity test of the $\mathrm{Cr} / \mathrm{ZrO}_{2}-\mathrm{SO}_{4}$ catalyst in the hydrocracking reaction of LDPE into liquid fuel has been carried out by Hauli et al. [72]. The hydrocracking reaction was carried out at a temperature of $250{ }^{\circ} \mathrm{C}$ using $\mathrm{ZrO}_{2}, \mathrm{SZ}, \mathrm{Cr} 1 / \mathrm{SZ}, \mathrm{Cr} 2 / \mathrm{SZ}$, and $\mathrm{Cr} 3 / \mathrm{SZ}$ catalysts. The percentages of conversion yields of the hydrocracking of each catalyst are presented in Table 10. The presence of sulfate and $\mathrm{Cr}$ metal in $\mathrm{ZrO}_{2}$ can increase the yield of liquid products from the hydrocracking reaction. The liquid product increased along with the increase in the amount of $\mathrm{Cr}$ metal deposited on $\mathrm{ZrO}_{2}$. This can be attributed to the role of acid sites in the catalyst (from sulfate and metal $\mathrm{Cr}$ ) which contribute to the active sites of the catalyst, thereby increasing its catalytic activity [50].

Table 10. Distribution of LDPE plastic hydrocrack products on various catalysts [72].

\begin{tabular}{cccc}
\hline \multirow{2}{*}{ Catalyst } & \multicolumn{3}{c}{ Product Conversion $\mathbf{( \% \mathbf { b } / \mathbf { b } )}$} \\
\cline { 2 - 4 } & Liquid & Coke & Gas \\
\hline $\mathrm{ZrO}_{2}$ & 17.39 & 0.36 & 32.23 \\
$\mathrm{SZ}$ & 28.72 & 0.34 & 29.51 \\
$\mathrm{Cr} 1 / \mathrm{SZ}$ & 33.48 & 0.01 & 25.78 \\
$\mathrm{Cr} 2 / \mathrm{SZ}$ & 40.99 & 0.01 & 24.84 \\
$\mathrm{Cr} 3 / \mathrm{SZ}$ & 37.51 & 0.01 & 26.77 \\
\hline
\end{tabular}

The highest conversion of liquid product was produced using the Cr2/SZ catalyst, which was $40.99 \%$, with a lesser amount of $37.51 \%$ with the use of the Cr3/SZ catalyst. Moreover, the Cr2/SZ catalyst had a higher acidity value than Cr3/SZ. In addition, the surface area of the catalyst also affects the catalytic activity of the catalyst in the hydrocracking of LDPE plastics [75,76]. Accordingly, the Cr2/SZ had a larger surface area, resulting in greater conversion. The modification of $\mathrm{Cr}$ on sulfated zirconia demonstrated a reduction in coke formation, thereby increasing the feed interaction on the active sites of the catalysts.

The selectivity of the catalysts towards liquid products in the hydrocracking reaction are shown in Figure 23. All the catalysts showed higher selectivity in the gasoline fraction than the diesel fraction. The presence of sulfate and $\mathrm{Cr}$ in sulfated zirconia increased the selectivity towards the gasoline fraction $\left(C_{5}-C_{12}\right)$ and decreased the selectivity towards the diesel fraction $\left(\mathrm{C}_{13}-\mathrm{C}_{20}\right)$, as expected. The highest selectivity of the gasoline fraction was obtained from the use of the $\mathrm{Cr} 2 / \mathrm{SZ}$ catalyst, which was at $93.42 \%$.

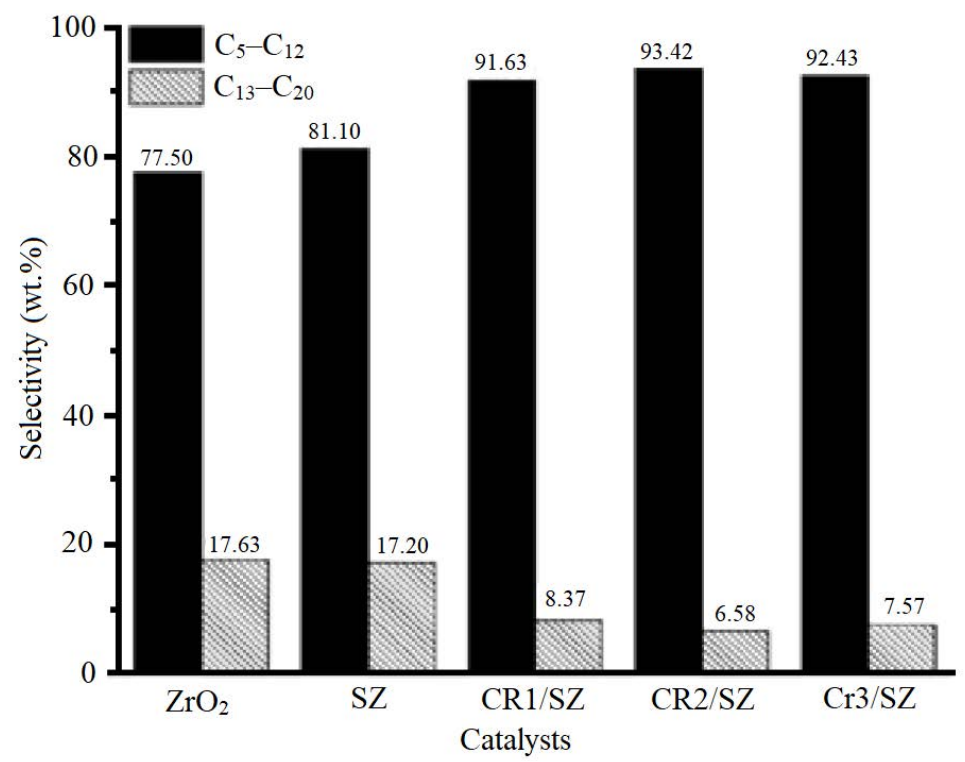

Figure 23. Liquid product selectivity of $\mathrm{ZrO}_{2}, \mathrm{SZ}, \mathrm{Cr} 1 / \mathrm{SZ}, \mathrm{Cr} 2 / \mathrm{SZ}$, and $\mathrm{Cr} 3 / \mathrm{SZ}$ catalysts. Reprinted with permission from Dr. Hauli, Ref. [72]. Copyright 2019 Trans Tech Publication. 


\section{6. $\mathrm{Ni} / \mathrm{ZrO}_{2}-\mathrm{SO}_{4}$ Catalyst}

\subsection{FITR Characterization of $\mathrm{Ni} / \mathrm{ZrO}_{2}-\mathrm{SO}_{4}$ Catalyst}

Research on the $\mathrm{ZrO}_{2}-\mathrm{SO}_{4}$ catalyst was also carried out about its application in the hydrocracking of used cooking oil into liquid fuel. Modification of $\mathrm{ZrO}_{2}-\mathrm{SO}_{4}$ with Ni metal has been reported by Aziz et al. [73]. Figure 24 show the FTIR spectra of Ni-SZ 1, Ni-SZ 2, and Ni-SZ 3. Impregnated $\mathrm{Cr}$ metal to SZ caused the presence of a new peak in the area of 1103 and $1141 \mathrm{~cm}^{-1}$, confirming the S-O-S stretching of from $\mathrm{SO}_{4}$ ion from SZ coordinated with Ni metal $[76,77]$. However, the sulfate spectra at $1002-1219 \mathrm{~cm}^{-1}$ disappear due to the Ni metal coverage on the SZ surface and the higher calcination temperature.

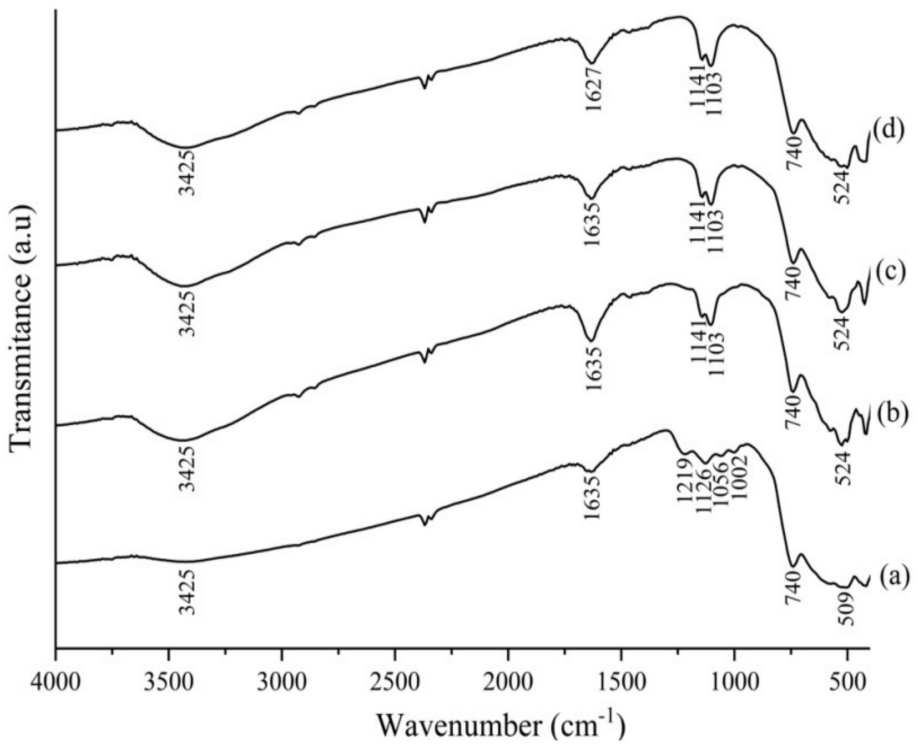

Figure 24. FTIR spectra of SZ (a), Ni-SZ 1 (b), Ni-SZ 2 (c), and Ni-SZ 3 (d) catalysts. Reprinted with permission from Aziz, Ref. [73]. Copyright 2020 Budapest University.

\subsection{Acidity and SAA Analysis of $\mathrm{Ni} / \mathrm{ZrO}_{2}-\mathrm{SO}_{4}$ Catalyst}

The total acidity and pore characteristic of Ni-SZ catalysts is shown in Table 11. It can be seen that the sulfation of $\mathrm{ZrO}_{2}$ (SZ catalyst) and Ni metal impregnated to SZ catalysts successfully increase the total acidity of the catalyst. Ni metal has a vacant $p$ orbital that will accepting electron pair and acts as a Lewis acid site [78]. The Ni-SZ 3 catalyst was the catalyst with the highest total acidity of $4.235 \mathrm{mmol} / \mathrm{g}$.

Table 11. The acidity and pore characteristics of the Ni-SZ catalysts [73].

\begin{tabular}{|c|c|c|c|c|}
\hline Sample & Acidity & $\begin{array}{c}\text { Surface Area } \\
\left(\mathrm{m}^{2} / \mathrm{g}\right)\end{array}$ & $\begin{array}{l}\text { Pore Diameter } \\
(\mathrm{nm})\end{array}$ & $\begin{array}{l}\text { Pore Volume } \\
\qquad\left(\mathrm{cm}^{3} / \mathrm{g}\right)\end{array}$ \\
\hline $\mathrm{ZrO}_{2}$ & 0.355 & 5.63 & 30.72 & 0.04 \\
\hline SZ & 2.004 & 4.04 & 35.84 & 0.04 \\
\hline Ni-SZ 1 & 3.905 & 7.09 & 3.82 & 0.06 \\
\hline $\mathrm{Ni}-\mathrm{SZ} 2$ & 4.061 & 8.75 & 3.82 & 0.05 \\
\hline Ni-SZ 3 & 4.235 & 11.68 & 3.82 & 0.05 \\
\hline
\end{tabular}

The pore characteristic of the catalyst shows the increase in surface area after the impregnation of $\mathrm{Cr}$ metal onto the SZ catalyst due to the highly dispersion of $\mathrm{Ni}$ metal on the pore and surface of the SZ catalyst [79]. However, the presence of Ni causing the form of pore-blocking that significantly decreases the pore diameter of Ni-SZ catalysts [72].

The selectivity of the $\mathrm{Ni}-\mathrm{ZrO}_{2}-\mathrm{SO}_{4}$ catalyst is shown in Table $12 . \mathrm{ZrO}_{2}$ and $\mathrm{SZ}$ catalysts were observed to have lower activity and selectivity than Ni-SZ due to the lowest acidity and surface area that will produce considerable amounts of coke (block the active site) 
and decreases the amount of liquid product [80,81]. The addition of Ni metal (Ni-SZ 3 catalyst) increased the acidity $(4.23 \mathrm{mmol} / \mathrm{g})$ and surface area $\left(11.68 \mathrm{~m}^{2} / \mathrm{g}\right)$ of $\mathrm{ZrO}_{2}$, thereby increasing its activity and selectivity in the hydrocracking process $[82,83]$. The largest amount of liquid product produced was gasoline with the highest selectivity was produced by the Ni-SZ 3 catalyst with the diesel fraction $\left(C_{5}-C_{12}\right)$ reached $100 \%$.

Table 12. Selectivity of $\mathrm{ZrO}_{2}, \mathrm{SZ}, \mathrm{Ni}-\mathrm{SZ} 1, \mathrm{Ni}-\mathrm{SZ} 2$, and Ni-SZ 3 catalysts in the hydrocracking reaction of used cooking oil into liquid fuel [73].

\begin{tabular}{ccccc}
\hline \multirow{2}{*}{ Catalyst } & \multicolumn{4}{c}{ Selectivity (wt \%) } \\
\cline { 2 - 5 } & $\left(\mathbf{C}_{\mathbf{1}}-\mathbf{C}_{\mathbf{4}}\right)$ & $\left(\mathbf{C}_{\mathbf{5}}-\mathbf{C}_{\mathbf{1 2}}\right)$ & $\left(\mathbf{C}_{\mathbf{1 3}}-\mathbf{C}_{\mathbf{2 0}}\right)$ & Non-Hydrocarbon \\
\hline $\mathrm{ZrO}_{2}$ & 1.86 & 77.31 & 19.26 & 1.57 \\
$\mathrm{SZ}$ & 1.93 & 67.83 & 28.15 & 2.54 \\
$\mathrm{Ni}$-SZ 1 & 0.00 & 51.59 & 15.16 & 33.25 \\
$\mathrm{Ni}-S Z 2$ & 0.00 & 87.01 & 12.99 & 0.00 \\
$\mathrm{Ni}-S Z 3$ & 0.00 & 100.00 & 0.00 & 0.00 \\
\hline
\end{tabular}

\section{Conclusions}

Zirconia and its modified heterogeneous catalyst forms hold great potential in hydrocracking reaction applications to convert LDPE waste into liquid fuels with their excellent activity, selectivity, and stability. The sulfation process on $\mathrm{ZrO}_{2}$ with various concentrations of sulfuric acid and calcination temperatures succeeded in increasing the acidity of $\mathrm{ZrO}_{2}$. The $\mathrm{ZrO}_{2}-\mathrm{SO}_{4}$ catalyst treated with Platinum $(\mathrm{Pt})$ and Chrome $(\mathrm{Cr})$ transition metals had significantly increased acidity. Characterization analyses confirmed that Pt and $\mathrm{Cr}$ metals had been successfully impregnated on the SZ surface. The percentage of liquid fraction obtained with the use of the $\mathrm{Pt} / \mathrm{ZrO}_{2}-\mathrm{SO}_{4}$ catalyst proofed better activity, selectivity, and stability than $\mathrm{Cr} / \mathrm{ZrO}_{2}-\mathrm{SO}_{4}$ and $\mathrm{ZrO}_{2}-\mathrm{SO}_{4}$. The optimum amount of liquid fraction produced from the hydrocracking reaction LDPE plastic waste with the $\mathrm{Pt} / \mathrm{ZrO} \mathrm{CO}_{4}-\mathrm{SO}_{4}$ calalyst was $67.515 \%$, while that from the $\mathrm{Cr} / \mathrm{ZrO}_{2}-\mathrm{SO}_{4}$ catalyst was $40.99 \%$. The development of $\mathrm{Ni}$ on the $\mathrm{ZrO}_{2}-\mathrm{SO}_{4}$ catalyst also demonstrated an increase in selectivity in the hydrocracking reaction of used cooking oil into liquid fuel. The selectivity of the Ni-SZ catalyst was found to be better than that of SZ. The percentages of gasoline fractions produced were $100 \%$.

\section{Future Suggestion}

Zirconia-based nanocatalysts have bright prospects for application in various industrial areas such as petroleum cracking, biofuel synthesis, pharmaceutical, and the synthesis of various organic materials. The potential application of sulfated nanozirconia catalysts is shown in the Figure 25. Due to characteristics such as being non-toxic and easy to regenerate, as well as having a large surface area and high thermal and structural resistance, nanozirconia catalysts also have the potential to be used in the pharmaceutical industry. Preliminary studies in our laboratory have shown that this catalyst has the potential to be used as a solid acid catalyst in the synthesis of nitrobenzene from benzene.

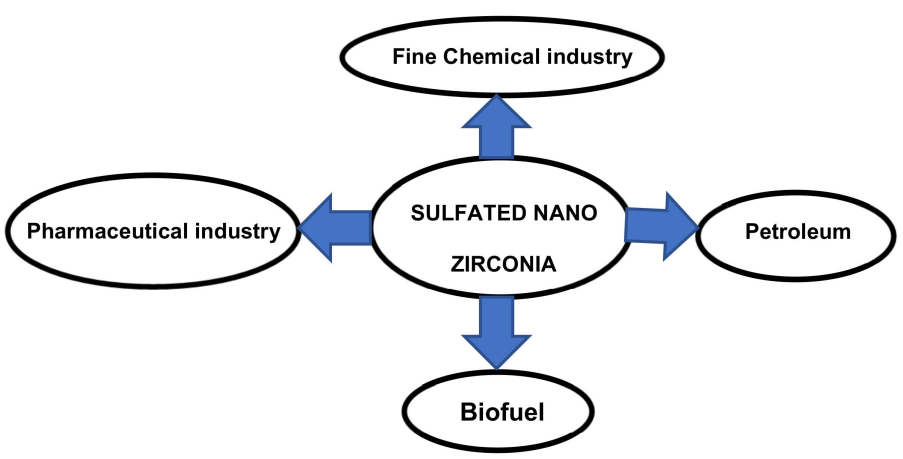

Figure 25. Potential application of sulfated nanozirconia catalysts. 
Author Contributions: Conceptualization, R.A.P., S.J.S., M.U., L.H. and A.K.A.; validation, R.A.P., M.U., L.H. and A.K.A.; investigation, R.A.P.; resources, R.A.P.; data curation, R.A.P., M.U., L.H. and A.K.A.; writing —original draft preparation, R.A.P. and S.J.S.; writing—review and editing, R.A.P.; visualization, K.W.; supervision, R.A.P. and K.W.; project administration, K.W.; funding acquisition, K.W. All authors have read and agreed to the published version of the manuscript.

Funding: This research was funded by Postdoctoral Research Grant Universitas Gadjah Mada (Contract Number: 6144/UN1/DITLIT/DIT-LIT/PT/2021).

Conflicts of Interest: The authors declare no conflict of interest.

\section{References}

1. Li, D.; Feng, W.; Chen, C.; Chen, S.; Fan, G.; Liao, S.; Wu, G.; Wang, Z. Transesterification of Litsea cubeba kernel oil to biodiesel over zinc supported on zirconia heterogeneous catalysts. Renew. Energy 2021, 177, 13-22. [CrossRef]

2. Hanafi, M.F.; Sapawe, N. Reusability study of zirconia catalyst toward photocatalytic degradation of Remazol brilliant blue dye. Mater. Today Proc. 2020, 31, 266-2688. [CrossRef]

3. Amin, A.K.; Trisunaryanti, W.; Wijaya, K. Effect of promoters and calcination temperature on surface and acidity of modified zirconia. J. Nano Res. 2018, 57, 31-39. [CrossRef]

4. Hauli, L.; Wijaya, K.; Armunanto, R. Preparation and characterization of sulfated zirconia from a commercial zirconia nanopowder. Orient. J. Chem. 2018, 34, 1559-1564. [CrossRef]

5. Yan, C.; Zheng, S.; Chen, N.; Yuan, S.; Chen, Y.; Li, B.; Zhang, Y. Sulfated zirconia catalysts supported on mesoporous Mg-SBA-15 with different morphologies for highly efficient conversion of fructose to 5-hydroxymethylfurfural. Micropor. Mesopor. Mater. 2021, 328, 111507. [CrossRef]

6. Utami, M.; Wijaya, K.; Trisunaryanti, W. Pt-promoted Sulfated Zirconia as Catalyst for Hydrocracking of LDPE Plastic Waste into Liquid Fuels. Mater. Chem. Phys. 2018, 213, 548-555. [CrossRef]

7. Yan, G.X.; Wang, A.; Wachs, I.E.; Baltrusaitis, J. Critical review on the active site structure of sulfated zirconia catalysts and prospects in fuel production. Appl. Catal. A. Gen. 2019, 572, 210-225. [CrossRef]

8. Wijaya, K.; Kurniawan, M.A.; Saputri, W.D.; Trisunaryanti, W.; Mirzan, M.; Hariani, P.L.; Tikoalu, A.D. Synthesis of nickel catalyst supported on $\mathrm{ZrO}_{2} / \mathrm{SO}_{4}$ pillared bentonite and its application for conversion of coconut oil into gasoline via hydrocracking process. J. Environ. Chem. Eng. 2021, 9, 105399. [CrossRef]

9. Utami, M.; Trisunaryanti, W.; Shida, K.; Tsushida, M.; Kawakita, H.; Ohto, K.; Wijaya, K.; Tominaga, M. Hydrothermal preparation of a platinum-loaded sulphated nanozirconia catalyst for the effective conversion of waste low density polyethylene into gasoline-range hydrocarbons. RSC Adv. 2019, 9, 41392-41401. [CrossRef]

10. Hauli, L.; Wijaya, K.; Syoufian, A. Fuel production from LDPE-based plastic waste over chromium supported on sulfated zirconia. Indones. J. Chem. 2019, 20, 422-429. [CrossRef]

11. Amin, A.K.; Trisunaryanti, W.; Wijaya, K. The Catalytic Performance of $\mathrm{ZrO}_{2}-\mathrm{SO}_{4}$ and Ni/ZrO $2-\mathrm{SO}_{4}$ Prepared from Commercial $\mathrm{ZrO}_{2}$ in Hydrocracking of LDPE Plastic Waste into Liquid Fuels. Orient. J. Chem. 2018, 34, 3070-3078. [CrossRef]

12. Treccani, L.; Klein, T.Y.; Meder, F.; Pardun, K.; Rezwan, K. Functionalized ceramics for biomedical, biotechnological and environmental applications. Acta Biomater. 2013, 9, 7115-7150. [CrossRef] [PubMed]

13. Skovgaard, M.; Gudik-Sorensen, M.; Almdal, K.; Ahniyas, A. Nanoporous zirconia microspheres prepared by salt-assisted spray drying. SN Appl. Sci. 2020, 2, 784. [CrossRef]

14. Utami, M. Platinum/Sulfated Nanozirconia: Preparation, Characterization, and Their Application in Conversion of LDPE Plastic Waste into Liquid Fuels. Ph.D. Thesis, Department of Chemistry, Universitas Gadjah Mada, Yogyakarta, Indonesia, 2019.

15. Le Ore, M.S.; Wijaya, K.; Trisunaryanti, W.; Saputri, W.D.; Heraldy, E.; Yuwana, M.W.; Hariani, P.L.; Budiman, A.; Sudiono, S. The Synthesis of $\mathrm{SO}_{4} / \mathrm{ZrO}_{2}$ and $\mathrm{Zr} / \mathrm{CaO}$ catalysts via hydrothermal treatment and their application for conversion of low-grade coconut oil into biodiesel. J. Environ. Chem. Eng. 2020, 8, 104205. [CrossRef]

16. Burger, W.; Kiefer, G. Alumina, zirconia and their composite ceramics with properties tailored for medical applications. J. Compos. Sci. 2021, 5, 306. [CrossRef]

17. Siddiqui, M.R.H.; Al-Wassil, A.I.; Alotaibi, A.M.; Mahfouz, R. Effects of precursor on the morphology and size of $\mathrm{ZrO}_{2}$ nanoparticles, synthesized by sol-gel method in non-aqueous medium. Mater. Res. 2012, 15, 986-989. [CrossRef]

18. Halter, W.; Eisele, R.; Rothenstein, D.; Bill, J.; Allgower, F. Moment dynamics of zirconia particle formation foe optimizing particle size distribution. Nanomaterials 2019, 9, 333. [CrossRef]

19. Maleki, F.; Pacchiono, G. Characterization of acid and basic sites on zirconia surfaces and nanoparticles by adsorbed probe molecules: A theoretical study. Top. Catal. 2020, 63, 1717-1730. [CrossRef]

20. Glorius, M.; Markovits, M.A.C.; Breitkopf, C. Design of specific acid-base-properties in $\mathrm{CeO}_{2}-\mathrm{ZrO}_{2}$-mixed oxides via templating and Au modification. Catalysts 2018, 8, 358. [CrossRef]

21. De Souza, E.F.; Appel, L.G. Oxygen vacancy formation and their role in the $\mathrm{CO}_{2}$ activation on Ca doped $\mathrm{ZrO} 2$ surface: An an-initio DFT study. App. Surf. Sci. 2021, 553, 149589. [CrossRef]

22. Song, L.; Cao, X.; Li, L. Engineering stable surface oxygen vacancies on $\mathrm{ZrO}_{2}$ by hydrogen-etching technology: An efficient support of gold catalysts for water-gas shift reaction. ACS Appl. Mater. Interfaces 2018, 109, 31249-31259. [CrossRef] [PubMed] 
23. Gautam, C.; Joyner, J.; Gautam, A.; Rao, J.; Vajtai, R. Zirconia Based Dental Ceramics: Structure, Mechanical Properties, Biocompatibility and Applications. Dalton Trans. 2016, 45, 19194-19215. [CrossRef] [PubMed]

24. Hauli, L.; Wijaya, K.; Syoufian, A. Hydrocracking of LDPE plastic waste into liquid fuel over sulfated zirconia from a commercial zirconia nanopowder. Orient. J. Chem. 2019, 35, 128-133. [CrossRef]

25. El-Desouki, D.S.; Ibrahim, A.H.; Abdelazim, S.M.; Aboul-Gheit, N.A.K.; Abdel-Hafizar, D.R. The optimum condition for methanol conversion to dimethyl ether over modified sulfated zirconia catalysts prepared by different methods. J. Fuel Chem. Technol. 2021, 49, 63-71. [CrossRef]

26. Yu, S.; Wu, S.; Li, L.; Ge, X. Upgrading bio-oil from waste cooking oil by esterification using $\mathrm{SO}_{4}{ }^{2-} / \mathrm{ZrO}_{2}$ as catalyst. Fuel 2020 , 276, 118019. [CrossRef]

27. Wang, P.; Yue, Y.; Wang, T.; Bao, X. Alkane isomerization over sulfated zirconia solid acid system. Int. J. Energ. Res. 2020, 44, 3270-3294. [CrossRef]

28. Rabee, A.I.M.; Mekhemer, G.A.H.; Osatiashtiani, A.; Isaacs, M.A.; Lee, A.F.; Wilson, K.; Zaki, M.I. Acidity-reactivity relationships in catalytic esterification over ammonium sulfate-derived sulfated zirconia. Catalysts 2017, 7, 204. [CrossRef]

29. Wang, P.; Zhang, J.; Han, C.; Yang, C.; Li, C. Effect of Modification Methods on the Surface Properties and $n$-Butane Isomerization Performance of La/Ni-Promoted $\mathrm{SO}_{4}{ }^{2-} / \mathrm{ZrO}_{2}-\mathrm{Al}_{2} \mathrm{O}_{3}$. Appl. Surf. Sci. 2016, 378, 489-495. [CrossRef]

30. Saravanan, K.; Tyagi, B.; Bajaj, H.C. Esterifcation of caprylic acid with alcohol over nano-crystalline sulfated zirconia. J. Sol-Gel Sci. Technol. 2012, 62, 13-17. [CrossRef]

31. Utami, M.; Wijaya, K.; Trisunaryanti, W. Effect of Sulfuric Acid Treatment and Calcination on Commercial Zirconia Nanopowder. Key Eng. Mater. 2017, 757, 131-137. [CrossRef]

32. Yang, X.; Ma, X.; Yu, X.; Ge, M. Exploration of strong metal-support interaction in zirconia supported catalysts for toluene oxidation. App. Catal. B Environ. 2020, 263, 118355. [CrossRef]

33. Mirzan, M.; Syoufian, A.; Wijaya, K. Physico-chemical properties of nano $\mathrm{ZrO}_{2}$-pillared bentonite with nickel as supporting metal. Nano Hybrids Compos. 2020, 30, 9-17. [CrossRef]

34. Loveless, B.T.; Gyanani, A.; Muggli, D.S. Discrepancy between TPD- and FTIR- based measurements of Brønsted and Lewis acidity for sulfated zirconia. Appl. Catal. B Environ. 2008, 84, 591-597. [CrossRef]

35. Li, L.; Yan, B.; Li, H.; Yu, S.; Liu, S.; Yu, H.; Ge, X. $\mathrm{SO}_{4}{ }^{2-} / \mathrm{ZrO}_{2}$ as catalyst for upgrading of pyrolysis oil by esterification. Fuel 2018, 226, 190-194. [CrossRef]

36. Pratika, R.A.; Wijaya, K.; Trisunaryanti, W. Hydrothermal treatment of $\mathrm{SO}_{4} / \mathrm{TiO}_{2}$ and $\mathrm{TiO}_{2} / \mathrm{CaO}$ as heterogeneous catalysts for the conversion of Jatropha oil into biodiesel. J. Environ. Chem. Eng. 2021, 9, 106547. [CrossRef]

37. Utami, M.; Safitri, R.; Pradipta, M.F.; Wijaya, K.; Chang, S.W.; Ravindran, B.; Ovi, D.; Rajabathar, J.R.; Poudineh, N.; Gengan, R.M. Enhanced catalytic conversion of palm oil into biofuels by Cr-incorporated sulphated zirconia. Mater. Lett. 2022, $309,131472$. [CrossRef]

38. Hanifah, A.; Nadia, A.; Saputri, W.D.; Syoufian, A.; Wijaya, K. Performance of Ni-Mo sulfated nanozirconia catalyst for conversion of waste cooking oil into biofuel via hydrocracking process. Mater. Sci. Forum 2021, 1045, 79-89. [CrossRef]

39. Sari, E.P.; Wijaya, K.; Trisunaryanti, W.; Syoufian, A.; Hasanudin, H.; Saputri, W.D. The effective combination of zirconia superacid and zirconia-imregnated $\mathrm{CaO}$ in biodiesel manufacturing: Utilization of used coconut cooking oil (UCCO). Int. J. Energ. Environ. Eng. 2021, 1-12. [CrossRef]

40. Wijaya, K.; Nadia, A.; Dinana, A.; Pratiwi, A.F.; Tikoalu, A.D.; Wibowo, A.C. Catalytic hydrocracking of fresh and waste frying oil over Ni- and Mo-based catalysts supported on sulfated silica for biogasoline production. Catalysts 2021, 11, 1150. [CrossRef]

41. Fernandez-Morales, J.M.; Castillejos, E.; Asedegbega-Nieto, E.; Dongil, A.B.; Rodrigues-Ramos, I.; Guerrero-Ruiz, A. Comparative study of different acidic surface structures in solid catalysts applied for the isobutene dimerization reaction. Nanomaterial 2020, 10, 1235. [CrossRef]

42. Purba, S.E.; Wijaya, K.; Trisunaryanti, W.; Pratika, R.A. Dealuminated and desilicated natural zeolite as a catalyst for hydrocracking of used cooking oil into biogasoline. Mediterr. J. Chem. 2020, 11, 74-83. [CrossRef]

43. Wijaya, K.; Malau, M.L.L.; Utami, M.; Mulijani, S.; Patah, A.; Wibowo, A.C.; Chandrasekaran, M.; Rajabathar, J.R.; Al-Lohedan, H. Synthesis, characterizations and catalysis of sulfated silica and nickel modified silica catalysts for diethyl ether (DEE) production from ethanol towards renewable energy applications. Catalysts 2021, 11, 1511. [CrossRef]

44. Serrano, D.P.; Garcia, R.A.; Linares, M.; Gil, B. Influence of the calcination treatment on the catalytic properties of hierarchical ZSM-5. Catal. Today 2012, 179, 91-101. [CrossRef]

45. Swamidoss, C.M.A.; Sheraz, M.; Anus, A.; Jeong, S.; Park, Y.-K.; Kim, Y.-M.; Kim, S. Effect of $\mathrm{Mg} / \mathrm{Al}_{2} \mathrm{O}_{3}$ and calcination temperature on the catalytic decomposition of HFC-134a. Catalysts 2019, 9, 270. [CrossRef]

46. Abedin, M.A.; Kanitkar, S.; Bhattar, S.; Spivey, J.J. Methane dehydroaromatization using Mo supported on sulfated zirconia catalyst: Effect of promoters. Catal. Today 2021, 365, 71-79. [CrossRef]

47. Susi, E.P.; Wijaya, K.; Wangsa; Pratika, R.A.; Hariani, P.L. Effect of nickel concentration in natural zeolite as catalyst in hydrocracking process of used cooking oil. Asian J. Chem. 2020, 32, 2773-2777. [CrossRef]

48. Yin, P.; Hu, S.; Qian, K.; Wei, Z.; Zhang, L.-L.; Lin, Y.; Huang, W.; Xiong, H.; Li, W.X.; Liang, H.-W. Quantification of critical particle distance for mitigating catalyst sintering. Nat. Commun. 2021, 12, 4865. [CrossRef]

49. Prašnikar, A.; Pavlišič, A.; Ruiz-Zepeda, F.; Kovač, J.; Likozar, B. Mechanism of Copper-based catalyst deactivation during $\mathrm{CO}_{2}$ reduction to methanol. Ind. Eng. Chem. Res. 2019, 58, 13021-13029. [CrossRef] 
50. Rahmati, M.; Safdari, M.S.; Fletcher, T.H.; Argyle, M.D.; Bartholomew, C.H. Chemical and thermal sintering of supported metals with emphasis on cobalt catalysts during Fischer-Tropsch synthesis. Chem. Rev. 2020, 120, 4455-4533. [CrossRef]

51. Zhou, S.; Song, Y.; Zhao, J.; Zhou, X.; Chen, L. Study on the Mechanism of Water Poisoning Pt-Promoted Sulfated Zirconia Alumina in n-Hexane Isomerization. Energy Fuels 2021, 35, 14860-14867. [CrossRef]

52. Peng, S.; Li, M.; Yang, X.; Li, P.; Liu, H.; Xiong, W.; Peng, X. Atomic layer deposition of Pt nanoparticles on $\mathrm{ZrO}_{2}$ based metal-organic frameworks for increased photocatalytic activity. Ceram. Int. 2019, 45, 18128-18134. [CrossRef]

53. Bikmetova, L.I.; Kazantsev, K.V.; Zatolokina, L.V.; Smolikov, M.D.; Belyi, A.S. A study on the synthesis steps of alumina-supported $\mathrm{Pt} / \mathrm{SO}_{4} / \mathrm{ZrO}_{2}$ catalysts for isomerization of n-hexane. AIP Conf. Proc. 2020, 2285, 020003. [CrossRef]

54. Souza, I.C.A.; Manfro, R.L.; Souza, M.M.V.M. Hydrogen production from steam reforming of acetic acid over Pt-Ni bimetallic catalysts supported on $\mathrm{ZrO}_{2}$. Biomass Bioenergy 2022, 156, 106317. [CrossRef]

55. Ullah, I.; Taha, T.A.; Alenad, A.M.; Uddin, I.; Hayat, A.; Hayat, A.; Sohail, M.; Irfan, A.; Khan, J.; Palamanit, A. Platinum-alumina modified $\mathrm{SO}_{4}{ }^{2-} \mathrm{ZrO}_{2} / \mathrm{Al}_{2} \mathrm{O}_{3}$ based bifunctional catalyst for significantly improved n-butane isomerization performance. Surf. Interfaces 2021, 25, 101227. [CrossRef]

56. Tamizhdurai, P.; Lavanya, M.; Meenakshisundaram, A.; Shanti, K.; Sivasanker, S. Isomerization of alaknes over Pt-sulphated zirconia supported on SBA-15. Adv. Porous Mater. 2017, 5, 169-174. [CrossRef]

57. Cho, H.J.; Kim, D.; Li, S.; Su, D.; Ma, D.; Xu, B. Molecular-level proximity of metal and acid sites in zeolite-encapsulated Pt nanoparticles for selective multistep tandem catalysis. ACS Catal. 2020, 10, 3340-3348. [CrossRef]

58. Gan, T.; Yang, J.; Morris, D.; Chu, X.; Zhang, P.; Zhang, W.; Zuo, Y.; Yan, W.; Wei, S.-H.; Liu, G. Electron donation of non-oxide supports boosts $\mathrm{O}_{2}$ activation on nano-platinum catalysts. Nat. Commun. 2021, 12, 2741. [CrossRef] [PubMed]

59. Aboul-Gheit, A.K.; Gad, F.K.; Abdel-Aleem, G.M.; El-Desouki, D.S.; Abdel Hamid, S.M.; Ghoneim, S.S.; Ibrahim, A.H. Pt, Re and Pt-Re incorporation in sulfated zirconia as catalysts for n-pentane isomerization. Egypt. J. Pet. 2014, 23, 303-314. [CrossRef]

60. Zhao, P.-P.; Chen, J.; Yu, H.-B.; Cen, B.-H.; Wang, W.-Y.; Luo, M.-F.; Lu, J.-Q. Insight into propane combustion over MoO 3 promoted $\mathrm{Pt} / \mathrm{ZrO}_{2}$ catalysts: The generation of $\mathrm{Pt}-\mathrm{MoO}_{3}$ interface and its promotional role on catalytic activity. J. Catal. 2020, 391, 80-90. [CrossRef]

61. Kondratowicz, T.; Drozdek, M.; Michalik, M.; Gac, W.; Gajewska, M.; Kustroski, P. Catalytic activity of Pt species variously dispersed on hollow $\mathrm{ZrO}_{2}$ spheres in combustion of volatile organic compounds. App. Surf. Sci. 2020, 513, 145788. [CrossRef]

62. Verga, L.G.; Rusell, A.E.; Skylaris, C.K. Ethanol, O, and CO adsorption on Pt nanoparticles: Effect of nanoparticle size and graphene support. Phys. Chem. Chem. Phys. 2018, 20, 25918-25930. [CrossRef] [PubMed]

63. Wang, S.; Pu, J.; Wu, J.; Liu, H.; Xu, H.; Li, X.; Wang, H. $\mathrm{SO}_{4}{ }^{2-} / \mathrm{ZrO}_{2}$ as a solid acid for the esterification of palmitic acid with methanol: Effects of the calcination time and recycle method. ACS Omega 2020, 5, 30139-30147. [CrossRef] [PubMed]

64. Ren, K.; Kong, D.; Meng, X.; Wang, X.; Shi, L.; Liu, N. The effect of ammonium sulfate and sulfamic acid on the surface acidity of sulfated zirconia. J. Saudi Chem. Soc. 2019, 23, 198-204. [CrossRef]

65. Vance, B.C.; Kots, P.A.; Wang, C.; Hinton, Z.R.; Quinn, C.M.; Epps, T.H., III; Korley, L.T.J.; Vlachos, D.G. Single pot catalyst strategy to branched products via adhesive isomerization and hydrocracking of polyethylene over platinum tungstated zirconia. App. Catal. B. Environ. 2021, 299, 120483. [CrossRef]

66. Liu, S.; Lots, P.; Vance, B.C.; Danielson, A.; Vlachos, D.G. Plastic waste to fuels by hydrocracking at mild conditions. Sci. Adv. 2021, 7, eabf8283. [CrossRef] [PubMed]

67. Chen, J.; Zhang, Y.; Chen, X.; Dai, S.; Bao, Z.; Yang, Q.; Ren, Q.; Zhang, Z. Cooperative interplay of Bronsted acid and Lewis acid sites in MIL-101 (Cr) for cross-dehydrogenative coupling of C-H. Bonds. ACS Appl. Mater. Interfaces 2021, 13, 10845-10854. [CrossRef] [PubMed]

68. Hu, Z.-P.; Wang, Z.; Yuan, Z.-Y. $\mathrm{Cr} / \mathrm{Al}_{2} \mathrm{O}_{3}$ catalysts with strong metal-support interactions for stable catalytic dehydrogenation of propane to propylene. Mol. Catal. 2020, 493, 111052. [CrossRef]

69. Annuar, N.H.R.; Triwahyono, S.; Jalil, A.A.; Basar, N.; Abdullah, T.A.T.; Ahmad, A. Effect of $\mathrm{Cr}_{2} \mathrm{O}_{3}$ loading on the properties and cracking activity of $\mathrm{Pt} / \mathrm{Cr}_{2} \mathrm{O}_{3}-\mathrm{ZrO}_{2}$. App. Catal. A Gen. 2017, 541, 77-86. [CrossRef]

70. Wang, H.; Lin, N.; Xu, R.; Yu, Y.; Zhao, X. First principles studies of electronic, mechanical and optical properties of Cr-doped cubic $\mathrm{ZrO}_{2}$. Chem. Phys. 2020, 539, 110972. [CrossRef]

71. Hauli, L. Chromium/Sulfated Nanozirconia: Preparation, Characterization, and Their Application in Conversion of LDPE Plastic Waste into Liquid Fuels. Ph.D. Thesis, Department of Chemistry, Universitas Gadjah Mada, Yogyakarta, Indonesia, 2019.

72. Hauli, L.; Wijaya, K.; Armunanto, R. Preparation of Cr metal supported on sulfated zirconia catalyst. Mater. Sci. Forum 2019, 948, 221-227. [CrossRef]

73. Aziz, I.T.A.; Saputri, W.D.; Trisunaryanti, W.; Sudiono, S.; Syoufian, A.; Budiman, A.; Wijaya, K. Synthesis of Nickel-loaded sulfated zirconia catalyst and its application for converting used palm cooking oil to gasoline via hydrocracking process. Period. Polytech. Chem. Eng. 2021, 66, 101-113. [CrossRef]

74. Tao, Y.; Zhu, Y.; Liu, C.; Yue, H.; Ji, J.; Yuan, S.; Jiang, W.; Liang, B. A highly selective $\mathrm{Cr} / \mathrm{ZrO}_{2}$ catalyst for the reverse water-gas shift reaction prepared from simulated $\mathrm{Cr}$-containing wastewater by a photocatalytic deposition process with $\mathrm{ZrO}_{2}$. J. Environ. Chem. Eng. 2018, 6, 6761-6770. [CrossRef]

75. Serrano, D.; Escola, J.; Briones, L.; Arroyo, M. Hydroprocessing of the LDPE thermal cracking oil into transportation fuels over Pd supported on hierarchical ZSM-5 catalyst. Fuel 2017, 206, 190-198. [CrossRef] 
76. Wong, S.L.; Ngadi, N.; Abdullah, T.A.T.; Inuwa, I.M. Conversion of low-density polyethylene (LDPE) over ZSM-5 zeolite to liquid fuel. Fuel 2017, 192, 71-82. [CrossRef]

77. Lyu, Y.; Xu, R.; Williams, O.; Wang, Z.; Sievers, C. Reaction paths of methane activation and oxidation of surface intermediates over NiO on Ceria-Zirconia catalysts studied by In-situ FTIR spectroscopy. J. Catal. 2021, 404, 334-347. [CrossRef]

78. Dahdah, E.; Estephane, J.; Gennequin, C.; Aboukais, A.; Abi-Aad, E.; Aouad, S. Zirconia supported nickel catalysts for glycerol steam reforming: Effect of zirconia structure on the catalytic performance. Int. J. Hydrogen Energy 2020, 45, 4457-4467. [CrossRef]

79. Kou, J.; Yi, L.; Li, G.; Cheng, K.; Wang, R.; Zhnag, D.; Jin, H.; Guo, L. Structural effect of $\mathrm{ZrO}_{2}$ on supported Ni-based catalysts for supercritical water gasification of oil-containing water. Int. J. Hydrogen Energ. 2021, 46, 12874-12885. [CrossRef]

80. Li, X.; Shao, Y.; Zhang, S.; Wang, Y.; Xiang, J.; Hu, S.; Xu, L.; Hu, X. Pore diameters of $\mathrm{Ni} / \mathrm{ZrO}_{2}$ catalysts affect properties of the coke in steam reforming of acetic acid. Int. J. Hydrogen Energy 2021, 46, 23642-23657. [CrossRef]

81. Kou, J.; Feng, H.; Wei, W.; Wang, G.; Sun, J.; Jin, H.; Guo, L. Study on the detailed reaction pathways and catalytic mechanism of a $\mathrm{Ni} / \mathrm{ZrO}_{2}$ catalyst for supercritical water gasification of diesel oil. Fuel 2022, 312, 122849. [CrossRef]

82. Papageridis, K.N.; Charisiou, N.D.; Douvartzides, S.L.; Sebastian, V.; Hinder, S.J.; Baker, M.A.; Alkhoori, S.; Polychronopoulou, K.; Goula, M.A. Effect of operating parameters on the selective catalytic deoxygenation of palm oil to produce renewable diesel over $\mathrm{Ni}$ supported on $\mathrm{Al}_{2} \mathrm{O}_{3}, \mathrm{ZrO}_{2}$, and $\mathrm{SiO}_{2}$ catalysts. Fuel Process. Technol. 2020, 209, 106547. [CrossRef]

83. Munir, M.; Ahmad, M.; Saeed, M.; Waseem, A.; Nizami, A.-S.; Sultana, S.; Zafar, M.; Rehan, M.G.; Srinivasan, G.R.; Ali, A.M.; et al. Biodeisel production from novel non-edible caper (Capparis spinosa L.) seeds oil employing $\mathrm{Cu}-\mathrm{Ni}$ doped $\mathrm{ZrO}_{2}$ catalyst. Renew. Sustain. Energy Rev. 2021, 138, 110558. [CrossRef] 